\title{
Towards the Coptic Church: The Making of the Severan Episcopate
}

\begin{abstract}
This article concerns a seminal moment in the history of eastern Christianity: the creation of the Severan episcopate in Egypt (from A.D. 575), and with it the radical bifurcation, for the first time, of the ancient Egyptian church. Updating the classic account of Jean Maspero in the light of more recent publications, it first examines the rapid decline of the Severan episcopate in the period after the Alexandrian patriarch Theodosius' exile (536), and the intense competition to replace him in the period between his death (566) and the consecration of Peter (575). Exploiting a wide range of evidence related to a new episcopate then created under Peter and his successor Damian, this article then examines the presence of certain Severan bishops in rural monasteries, and the origins of an unprecedented office, the patriarchal vicarate, in the context of the competition created through the creation of a raft of rival sees. Understanding these processes, it is argued, is crucial to appreciating the explosion of evidence which accompanies the patriarchate of Damian.
\end{abstract}

\section{Introduction}

At some point around 600 C.E., according to an extant Coptic encomium, a delegation of clerics dispatched from Alexandria arrived in the distant Thebaid, bearing the festal letter of the patriarch Damian. Here the delegation attended upon the encomium's protagonist, Pesynthius bishop of Koptos, and were present beside him when an itinerant shepherd from a neighbouring region arrived to receive the bishop's blessing. When the shepherd approached Pesynthius, in the encomium's telling, the latter dramatically proclaimed him a sinner, and called upon his disciple John (one of the encomium's authors) to remove him. Outside, the shepherd confessed to John his recent rape of a local girl, and persuaded him to accept some cheeses for the patriarch's clerics. When however in the evening the shepherd's cheeses were served alongside some others, Pesynthius, with miraculous discernment, separated them out, censured his disciple, and commanded him to return them. ${ }^{1}$

\footnotetext{
I am much indebted to Edward Zychowicz-Coghill and Marek Jankowiak for their criticisms of, and corrections to, an earlier version of this article, and to an anonymous reviewer for numerous suggestions which greatly improved the text.
}

1 Encomium on Pesynthius (Short Sahidic Version) ed. E. A. W. Budge, Coptic Apocrypha in the Dialect of Upper Egypt, London 1913, 75-127, at 105-109. Henceforth note that in the first instance of citing a source, I also give the critical edition. Thereafter I refer to the subdivisions within that edition, but 
At first sight, both the contents and setting of this episode might seem somewhat commonplace, perhaps even cliché. But when considered in the light of further evidence, both emerge as rather remarkable. It is demonstrable, first of all, that the event described is not a product of the hagiographer's imagination, for it is also memorialised, from a more prosaic perspective, in a contemporaneous Coptic document (P.Pisentius 54), in which one Calapesius petitions the bishop Pesynthius, on behalf of a girl's parents, to pass sentence on a shepherd who has raped her. ${ }^{2}$ The case of the shepherd, moreover, also occurred at a moment of dramatic institutional change, which the casual reader of the encomium, and the associated document, might well not appreciate. The arrival of the patriarch's festal letter was, in one perspective, an annual occurrence which was now centuries old. But in Pesynthius's generation it had become something far more contentious - for Damian presided over an emergent, anti-Chalcedonian episcopate, and his emissaries now traversed the land alongside, and as rivals to, those of another, Chalcedonian, patriarch at Alexandria. At the same time, it is probable that Damian's delegation attended upon Pesynthius not in his titular see, that of Koptos, but rather at a distant monastic retreat within the ancient necropolis of Western Thebes, whence derive, it seems, a large number of documents which form the bishop's archive (including P.Pisentius 54). ${ }^{3}$ When situated within its wider evidential and historical context, therefore, our case of the shepherd not only provides a rare case in which a hagiographic vignette is demonstrably based in an actual event, ${ }^{4}$ but also points to the recent, radical, bifurcation of the Alexandrian patriarchate, and of the presence of a prominent member of the new, anti-Chalcedonian, episcopate within a rural monastery.

This paper explores the formation of this new church. It first of all looks to fill a lacuna in current scholarship, by setting out the available evidence for the formation of the anti-Chalcedonian, Severan church over which Damian presided in Egypt, and the context from which it emerged. Since the 1950s a large corpus of research has afforded us an ever-more sophisticated understanding of the structural and cultural formation of the Severan church elsewhere within the Near East, a process which began from $c .553 .^{5}$ But the student who wishes to understand the same process in Egypt - starting some two decades later, from c.575 - must for the most part still de-

also give the particular page of the edition when translating from it, or when the subdivision is too imprecise for a reader to locate the passage to which I refer.

2 P. Pisentius ed. E. Revillout, "Textes coptes extraits de la correspondance de St. Pésunthius évêque de Coptos et de plusieurs documents analogues (juridiques ou économiques)," Revue égyptologique 9, 1900, 133-177; 10, 1902, 34-47; 14, 1912, 22-32 (here 10, 1902, 38-39).

3 See below pp. $174-175$.

4 A further parallel between the archive (P.Pisentius 15-16) and the Encomium (ed. Budge 115-119) is explored in J. van der Vliet, "Pisenthios de Coptos (569-632). Moine, évêque et saint. Autour d'une nouvelle édition de ses archives," in M-F. Boussac (ed.), Autour de Coptos: Actes du colloque organisé au Musée des Beaux-Arts de Lyon, mars 2000, Lyon 2002, 61-72, at 66-70.

5 See e.g. E. Honigmann, Évêques et évêchés monophysites d'Asie antérieure au VI siècle, Louvain 1951; V. Menze, Justinian and the Making of the Syrian Orthodox Church, Oxford 2008. 
pend on the relevant sections of Jean Maspero's Histoire des patriarches d'Alexandrie, published unfinished after the author's tragic death during the First World War. ${ }^{6}$ Though outdated in certain of its emphases, Maspero's monograph remains a masterpiece of scholarship, but he did not have access to a significant number of important texts since published in Syriac and in Coptic or Copto-Arabic, as well as a large number of relevant papyri and ostraca. Here, then, I offer a revised account of the emergence of the Severan church in Egypt, and attempt to integrate the insights of sources not available to Maspero.

The aforementioned Pesynthius of Koptos belongs to a circle of bishops who, under Damian, gain sudden prominence across a range of extant media: manuscripts, documents, and artefacts. Elsewhere I have set out in detail the nature and content of this evidence, but here I want to outline the historical processes, and institutional reforms, which enabled its existence. ${ }^{7}$ Coptologists have sometimes presented the patriarchate of Damian as a 'golden age' of Coptic literature, in which the language gained a new independence and sophistication, and in which the production of original texts (in distinction to translations or pseudepigrapha) moved, for the first time, outside of the monasteries to embrace the more public sphere of the episcopate. ${ }^{8}$ But it is seldom acknowledged that this remarkable production depended upon, and indeed reinforced, a process of radical ecclesial formation, a process which created a new, anti-Chalcedonian, Severan patriarch in Alexandria, which reversed the near-extinction of the Severan episcopate in the wider province, and which inaugurated those rival bishoprics from which the earliest incumbents set about their remarkable production of new texts. We shall see, however, that this new patriarchate was not a simple imitation of its Chalcedonian equivalent: for the hierarchical organisation of the new church in Egypt departed from established ecclesiological norms both in the residence of some bishops within rural monasteries, and in its institution of a new office, the patriarchal vicarate. If we wish to com-

\footnotetext{
6 J. Maspero, Histoire des patriarches d'Alexandrie depuis la mort de l'empereur Anastase jusqu'à la réconciliation des églises jacobites (518-616) (Paris 1923). A huge amount of material relevant to Egypt can however be found in Honigmann, Évêques (cf. n. 5). More recent narrative accounts e.g. W. H. C. Frend, The Rise of the Monophysite Movement: Chapters in the History of the Church in the Fifth and Sixth Centuries, Cambridge 1972; S. J. Davis, The Early Coptic Papacy: The Egyptian Church and Its Leadership in Late Antiquity, Cairo 2004 - are broader in scope but less detailed for this period.

7 Cf. P. Booth, "A Circle of Egyptian Bishops at the End of Roman Rule (c.600): Texts and Contexts", Le Muséon 131 (2018, forthcoming).

8 See e.g. the influential contributions of T. Orlandi, Elementi di lingua e letteratura copta, Milan 1970, 97-106; id. "Coptic Literature," in B. A. Pearson - J. E. Goehring (eds.), The Roots of Egyptian Christianity, Philadelphia 1986, 51-81, at 75-77; id. "Letteratura copta e cristianesimo nazionale egiziano," in A. Camplani (ed.), L'Egitto cristiano: Aspetti e problemi in età tardo-antica, Rome 1997, 39 120, at 113-120; id., "Koptische Literatur," in M. Krause (ed.), Ägypten in spätantik-christlicher Zeit: Einführung in die koptische Kultur, Wiesbaden 1998, 117-147, at 144-145.
} 
prehend the evident efflorescence of episcopal culture under Damian, therefore, we must first comprehend the structural changes which it presupposed.

\section{The Decline of the Severan Communion}

Since the accession of the emperor Justin I in 518, and the simultaneous deposition of Severus patriarch of Antioch, the situation of those Christian bishops who resisted the Council of Chalcedon had become ever more insecure. From 521 anti-Chalcedonian bishops throughout the east had been pressed to submit to a Chalcedonian confession: some capitulated; some perhaps withdrew to monasteries; but others still went into exile at Alexandria. ${ }^{9}$ Egypt had not been a focus of persecution, and the province thus provided something of a safe haven for the recusants. But the concentration of exiles brought otherwise disparate theologians into contact, and it was now that the first serious dogmatic divisions emerged within the anti-Chalcedonian communion, focussed on the doctrine of aphthartism (the belief that Christ's body was incorruptible before its resurrection, associated with the exiled bishop Julian of Halicarnassus). ${ }^{10}$ The conflict between the supporters of Severus and those of Julian indeed reached such a pitch that when Theodosius, an associate of Severus, succeeded to the patriarchal throne in 535, the Julianists elected their own counter-patriarch, Gaianus, and Theodosius had to be restored through secular force, and Gaianus sent into exile. ${ }^{11}$ Then in 536 Justin's successor Justinian reinvigorated the persecution, and issued a novella which removed all remaining anti-Chalcedonian bishops from their cities. ${ }^{12}$ Egypt was no longer excluded. As a result, Theodosius and (at least some of) his bishops are said to have withdrawn from Alexandria and travelled to Constantinople - here the patriarch remained until his death in 566. ${ }^{13}$ In his stead was elected as patriarch Paul the Tabennesiote, and thus began a series of Chalcedonian patriarchs in Alexandria.

9 A list of over fifty exiles is provided (with some variations) in Chronicle of Zuqnin ed. J.-B. Chabot, Incerti auctoris chronicon anonymum pseudo-Dionysianum vulgo dictum, 2 vols, Louvain 1927-1933, vol. 2, 17-18; Michael the Syrian, Chronicle 9.13; and cf. Chronicle to 846 ed. E. W. Brooks in Chronica Minora II, Paris 1960, 157-238, at 225-228.

10 On Julianism see esp. A. Kofsky, "Julianism after Julian of Halicarnassus," in B. Bitton-Ashkelony - L. Perrone (eds.), Between Personal and Institutional Religion: Self, Doctrine, and Practice in Late Antique Eastern Christianity, Turnhout 2013, 251-294; and U. Possekel, "Julianism in Syriac Christianity," in P. Bruns - H. O. Luthe (eds.), Festschrift für Hubert Kaufhold zum 70. Geburtstag, Wiesbaden 2013, 437-458. On Julian and his thought: A. Grillmeier - T. Hainthaler, Christ in Christian Tradition, 2 vols, London and Oxford 1975-2013, vol. 2, pt. 2, 79-111.

11 See the useful account in A. Łajtar - E. Wipszycka, "L'epitaphe de Duhêla SB III 6249: les moines gaïanites dans les monastères alexandrins," Journal of Juristic Papyrology 28, 1998, 55-70, at 62-66. 12 Justinian, Novels 42. Further legal restrictions on Severanism: ibid. 109, 115, 131, 132.

13 For Theodosius's withdrawal see John of Ephesus, Lives of the Eastern Saints ed. E. W. Brooks, Patrologia Orientalis 17-19, here PO 18528 (leaving with all 'the notables of his jurisdiction', num- 
Through such persons as John of Tella, efforts had been made to maintain the provision of anti-Chalcedonian priests within Mesopotamia and the Levant, and various churches and monasteries must have remained committed to an anti-Chalcedonian confession. But at the time of Severus's death in 538, it appears that the effects of official persecution within the Antiochene patriarchate had all but eliminated the Severan episcopate there, its members now deceased, defected, or in exile. ${ }^{14} \mathrm{An}$ observer in 540, then, might well have supposed that Severanism would soon be consigned to the same slow decline as, for example, the various anti-Nicene movements. But in 542/3, Theodosius from his exile made a portentous move. Upon the reported request of the Jafnid leader al-Harith, and through the mediation of the empress Theodora, he appointed two bishops to minister to the anti-Chalcedonian faithful within the Near East: Jacob Baradeus as metropolitan of Edessa, and Theodore as bishop of Bostra. ${ }^{15}$ At first, it seems, the pair appointed nothing more than priests, but from c.553 Jacob began to consecrate other bishops. ${ }^{16}$ By 566, when John of Ephesus composed the Life of Jacob Baradeus now embedded in his Lives of the Eastern Saints, Jacob had appointed fifteen named bishops throughout Asia Minor, the Levant, and Mesopotamia ${ }^{17}$ - including the appointment of a rival Antiochene patriarch, Sergius of Tella, in $c .557 .{ }^{18}$ Although the numbers are minute in comparison to the numbers of actual sees within the east, Jacob had through his actions created the foundations of a new Jacobite episcopate. It seems certain, however, that these new Jacobite bishops, unlike their Chalcedonian equivalents, resided not in their titular cities, but in rural monasteries. ${ }^{19}$

In Egypt the creation of a new episcopate did not occur until a generation later. Such sources as exist for the period of Theodosius's exile (536-566) emphasise the deportation of anti-Chalcedonian bishops alongside the patriarch, but each differs on the suggested scale, and none provides a register of names. ${ }^{20}$ The two named

bering some three hundred bishops and clerics when in Constantinople); Ps.-Zachariah Rhetor, Chronicle 10.1 ed. F. J. Hamilton and E. W. Brooks, The Syriac Chronicle known as that of Zachariah of Mitylene, London 1899 (leaving with a few of his bishops); Michael the Great, Chronicle 9.21-22 ed. J.-B. Chabot, Chronique de Michel le Syrien, Patriarche Jacobite d'Antioche (1166-1199), 4 vols, Paris 1899-1910 (bishops not mentioned).

14 For detailed accounts see Honigmann, Évêques (cf. n. 5) esp. 142-154; A. Van Roey, "Les débuts de l'Église jacobite," in A. Grillmeier - H. Bacht (eds.), Das Konzil von Chalkedon: Geschichte und Gegenwart, 3 vols, Würzburg 1951, vol. 2, 339-360; Menze, Making of the Syrian Orthodox (cf. n. 5).

15 See John of Ephesus, Lives of the Eastern Saints (ed. Brooks PO 18 693; PO 19 153-154). On Theodore's activities see Honigmann, Évêques (cf. n. 5) 163-164.

16 See Honigmann, Évêques (cf. n. 5) 169-170.

17 Note that I exclude the twelve (unnamed) bishops said to have been consecrated for Egypt; see below pp. 161-162.

18 See John of Ephesus, Lives of the Eastern Saints (ed. Brooks PO 18 689; PO 19 156-157), with E. W. Brooks, "The Patriarch Paul of Antioch and the Alexandrian Schism of 575," Byzantinische Zeitschrift 30, 1930, 468-76, at 469, for the date.

19 Honigmann, Évêques (cf. n. 5) 173-174.

20 See above n. 13. 
Egyptian bishops known to have withdrawn are John of Hephaestopolis and John of Pelusium. ${ }^{21}$ Did the patriarch make some provision within Egypt for his absence? It has sometimes been assumed that this period witnessed the creation of a new institution, the patriarchal vicarate, through which the patriarch ceded certain powers over, for example, appointments and discipline - to a subordinate bishop. Thus a reference within the title to a fragmentary Coptic encomium on Saint Colluthus claims as its author one Phoibammon bishop of Panopolis, 'vicar of the entire country of Egypt (пилатохос птехора тнрс пкнме),' and presents him as a dependant of Theodosius, and a participant in the patriarch's exile. ${ }^{22}$ Nothing else is known of this Phoibammon, but since the encomium also claims to have been delivered at the saint's shrine at Pneuit, near Panopolis, it has been suggested that the reference to his participation in the patriarch's exile applies not to the period in Constantinople, but rather to Theodosius's brief withdrawal from Alexandria in 535, under pressure from his Julianist rival Gaianus. Thus it could be that Phoibammon served as

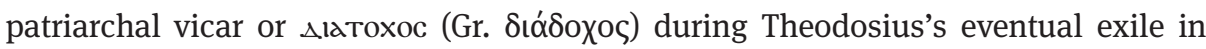
Constantinople. ${ }^{23}$

The recent publication of the full Arabic version of the encomium, however, demonstrates that the information presented in the text is insecure. ${ }^{24}$ The Coptic text gives out with Theodosius at Constantinople, but the Arabic continues to recount how, at the bequest of 'the emperor', Theodosius gathered all his bishops to him for a council, and that the bishops remained here for three years as exiles. After this the emperor started to release the bishops, who returned to their respective cities in Egypt for six months. At the instigation of 'the heretics' (sc. Chalcedonians), however, the emperor again summoned Theodosius and all his bishops, but when all were about to set sail, the patriarch instructed the author, Phoibammon, to remain, appointing him 'vicar' (نائب) ${ }^{25}$ with the power to ordain and to consecrate from Alexandria to Nubia. ${ }^{26}$ Phoibammon then claims that he wandered from city to city for four years (without mentioning ordinations), before Theodosius and all the bishops were again released, and returned to Alexandria once more. We are presented, then, with a

21 John of Hephaestopolis is the subject of John of Ephesus's twenty-fifth Life in Lives of the Eastern Saints (ed. Brooks PO 18 526-540). He was, according to John, a monastic refugee at the Ennaton whom Theodosius appointed (thus in 535 or 536). For John of Pelusium see below n. 56.

22 Phoibammon of Panopolis, Second Encomium on Colluthus ed. G. Schenke, Das koptisch hagiographische Dossier des heiligen Kolluthos: Arzt, Märtyrer und Wunderheiler, CSCO 650, Leuven 2013, at 160 -162. For diadochos and the vicarate cf. below p. 185.

23 See e.g. the discussion of P. Grossmann, "Phoibammon von Panopolis und das Kolluthos Martyrium in Pnewit," Journal of Coptic Studies 12, 2010, 19-31, esp. 23-24.

24 Y. Nessim Youssef, "The Second Encomium of Phoibammon on Saint Colluthus," Bulletin de la Société d'archéologie copte 50, 2011, 123-171, with 130-131 on the probable origins of the text in the eighth or ninth century.

25 This is significant, since it demonstrates that the Arabic نائب renders (at least sometimes) an orig-

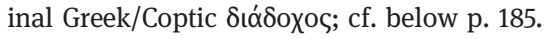

26 Youssef, “Second Encomium” (cf. n 24) 135. 
picture in which the patriarch and his episcopal colleagues oscillate between Alexandria and Constantinople, but this picture belongs to the realm of later legend Theodosius, once he had left his province, in fact never returned. It becomes far more difficult, therefore, to accept that the anti-Chalcedonian bishop 'Phoibammon of Panopolis' was indeed active in the period of Theodosius's exile, and that he served as patriarchal vicar. Indeed, as we shall see below, the creation of the vicarate seems in fact to have been an innovation of the new Severan episcopate which arose in the late 570s.

A dearth of detailed evidence means that we will never know the extent to which the episcopate on the eve of Theodosius's departure was divided between Severans and Julianists, that is, the amount of support which Theodosius commanded amongst his province's bishops; nor can we know the numbers of Severan bishops who, in 536, entered into exile alongside their patriarch. Did some Severans in fact remain in their sees? We cannot be sure. ${ }^{27}$ Some Egyptian sources remember the Chalcedonian patriarch Paul the Tabennesiote (538-540) as a persecutor ${ }^{28}$ (while maintaining a strange silence about his successor Zoilus [540-551]). ${ }^{29}$ But the same reports are late, anecdotal, and recounted with the evident purpose of lionising the victims and delegitimising their purported oppressors. ${ }^{30}$ Such reports are, moreover, limited to events in Alexandria. For the chora, hagiographic sources also describe the reign of Justinian (527-565) as one of persecution, ${ }^{31}$ but once again it is difficult to determine the nature, duration, and pervasiveness of such persecution. Those sources as exist focus not on bishops but on ascetics, and the most detailed - the hagiographic corpus of Abraham of Farshut - points not to universal suppression so much as the ad hoc removal of prominent archimandrites. ${ }^{32}$ Perhaps, then, 'persecution' in Egypt constituted a similar process to that which we now rec-

27 The names of some contemporaneous bishops are known from documents (e. g. John of Aphrodito [539/554]: P.Michael 41.69), but there is no indication of their doctrinal inclinations; see K. A. Worp, "A Checklist of Bishops in Byzantine Egypt (A.D. 325 - c.750)," Zeitschrift für Papyrologie und Epigraphik 100, 1994, 283-318.

28 See esp. History of the Patriarchs (Vulgate Recension) ed. B. Evetts, History of the Patriarchs of the Coptic Church of Alexandria, Patrologia Orientalis 1, 5, 10 (here, PO $1465-470$ ).

29 For the patriarchal dates: A. Jülicher, "Die Liste der alexandrinischen Patriarchen im 6. und 7. Jahrhundert," in Festgabe von Fachgenossen und Freunden Karl Müller zum siebzigsten Geburtstag dargebracht, Tübingen 1922, 7-23, at 18-19.

30 Pace Maspero, Histoire des patriarches (cf. n. 6) 143-151, who refers to the period as 'la terreur catholique.' But cf. ibid. 178-179 where the evidence for persecution is treated with more caution. 31 See e.g. D. W. Johnson, “Anti-Chalcedonian Polemics in Coptic Texts, 451-641," in Pearson Goehring, Roots of Egyptian Christianity (cf. n. 8) 216-234; J. E. Goehring, Politics, Monasticism, and Miracles in Sixth Century Upper Egypt, Tübingen 2012.

32 See esp. J. E. Goehring, "Chalcedonian Power Politics and the Demise of Pachomian Monasticism," Occasional Papers of the Institute for Antiquity and Christianity 15, 1989, 1-20. Cf. also John of Ephesus, Lives of the Eastern Saints (ed. Brooks PO 18 630), pointing to the widespread expulsion (but not, here, explicit deportation) of Egyptian bishops and the targeting of prominent monastic leaders. 
ognise in Syria: a general ostracisation of recusant bishops from cities and, alongside it, the more targeted deposition of recalcitrant monastic leaders. ${ }^{33}$ In this case we might imagine an extended, piecemeal process through which some bishops went into exile; some recognised Chalcedon; and those that remained either died or were deposed, in both cases being replaced with those more amenable to the Chalcedonian patriarchs in Alexandria.

Something of the complexities of this process is perhaps captured in precious echoes from the patriarchate of Apollinarius (551-569/70), the successor of Zoilus. ${ }^{34}$ In some later sources Apollinarius is presented as a persecutor, ${ }^{35}$ but the pro-Severan Chronicle of John of Nikiu (c.690) embeds two striking passages which might suggest that the patriarch was a more complex figure. Following a section of text which offers brief descriptions of the patriarchates of Paul and Zoilus, the Chronicle calls Apolli-

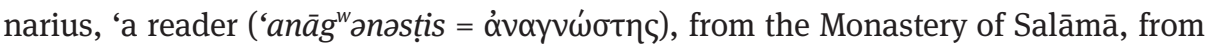
the city of Alexandria, called Apollinarius (yulinäryos), and he was merciful, and an adherent (dammād) of the people of the Theodosians (tāwadosāwyān). ${ }^{36}$ Then, in a subsequent section on Justinian's late acceptance of aphthartism (in 565) we read that, 'Thereafter [Justinian] sent a letter to Agathon the official (śyyum) over the city of Alexandria, that he establish Apollinarius (yulināryos) qomos (= ìyoú $\mu \varepsilon v o \varsigma$ ) of the Monastery of Bānțon as Chalcedonian patriarch in the city of Alexandria, and in the other cities of Egypt. ${ }^{37}$ According to both traditions - which must derive from different sources - Apollinarius was therefore a cleric or monk at the famous complex of monasteries situated nine miles west of Alexandria, the Ennaton: the Monastery of Salama can be otherwise placed there; ${ }^{38}$ and the Ethiopic Bānțon is a common corruption, via Arabic, of the Greek/Coptic "Evvatov. ${ }^{39}$

Maspero dismissed the Chronicle's evidence, presuming that the Ennaton which had in the 520s provided a refuge for various anti-Chalcedonian luminaries, where the relics of Severus of Antioch were laid, and which would later serve as

33 For the situation of anti-Chalcedonian monasteries in Justinianic Syria: Menze, Making of the Syrian Orthodox (cf. n. 5) 106-144.

34 For the dates Jülicher, "Die Liste” (cf. n. 29) 18-19.

35 E.g. History of the Patriarchs (Vulgate Recension) (ed. Evetts PO 1469 -472); Chronicon Orientale ed. P. L. Cheikho, Petrus Ibn Rahib Chronicon Orientale, Paris 1903, 119; Eutychius, Annals (Alexandrian Recension) ed. M. Breydy, Das Annalenwerk des Eutychios von Alexandrien, 2 vols, Louvain 1985, vol. 1, 104-105.

36 John of Nikiu, Chronicle 92 ed. H. Zotenberg, Chronique de Jean, évêque de Nikiou, Paris 1883, 162. 37 John of Nikiu, Chronicle 94 (ed. Zotenberg 165).

38 John Moschus, Spiritual Meadow 145 (ed. PG 87, here 3008C: tò кoเvóßıv $\Sigma \alpha \lambda \alpha \mu \tilde{\alpha}$; noting that the

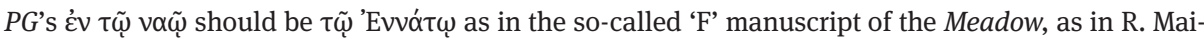
sano, Il Prato, Naples 1982, 246). This institution is perhaps identical with the 'Monastery of Shalaman' (šlmn) which appears in Zachariah Rhetor, Life of Severus of Antioch (ed. M.-A. Kugener, Vie de Sévère, par Jean, superieur du monastère de Beith Aphthonia, Patrologia Orientalis 2, at 14) named after the person who then presided over the Ennaton (ibid. 15).

39 Cf. Maspero, Histoire des patriarches (cf. n. 6) 158-161, with the notes. 
the patriarchal residence for Peter IV and Damian ${ }^{40}$ - could not have supplied a patriarch who supported Chalcedon. ${ }^{41}$ Perhaps we should imagine that the doctrinal politics of the monasteries which comprised the Ennaton were far more complex than a total adherence to anti-Chalcedonism - this is without doubt true of later decades. ${ }^{42}$ But there also survives a letter from Justinian To the Monks in the Ennaton of

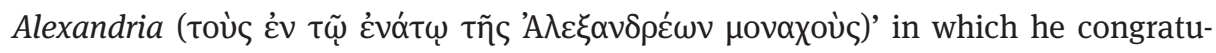
lates the recipients for submitting to Apollinarius's predecessor, the patriarch Zoilus. ${ }^{43}$ We might in fact infer, then, that Apollinarius was a former adherent of Theodosius who, along with some associates at the Ennaton, reconciled himself to the new Alexandrian regime, and was later elevated to the patriarchate, perhaps as an example to other potential converts. At the least, there seems little reason to doubt John of Nikiu's sources; but in this case it is quite striking that at least some ascetics within the Ennaton, otherwise perceived as a citadel against Chalcedon, had somehow come to terms with the council.

We might imagine that other contemporaries, including at least some of those who then formed Apollinarius's episcopate, did the same. In the Acts of the Fifth Ecu-

40 On the Ennaton see J. Gascou, "Enaton, The," in A. S. Atiya (ed.), The Coptic Encyclopedia, 8 vols, New York 1991, 954-958; S. Timm, Das christlich-koptische Ägypten in arabischer Zeit, 7 vols, Wiesbaden 1984-1992, 833-853.

41 Cf. Maspero, Histoire des patriarches (cf. n. 6) 158-161.

42 For members of the Ennaton in Chalcedonian texts see John Moschus, Meadow 145, 146, 171, 177, 184. To these can be added the further Moschan tale (not in $P G$ ) staged with Sophronius at the En-

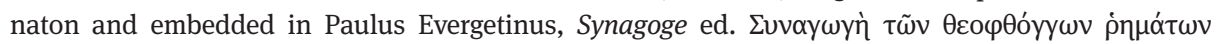

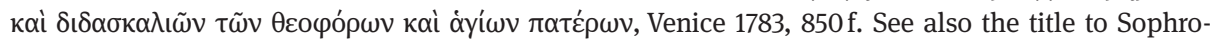
nius, Anacreontics 21 ed. M. Gigante, Sophronii Anacreontica, Rome 1957, 128, dedicated to Menas oi-

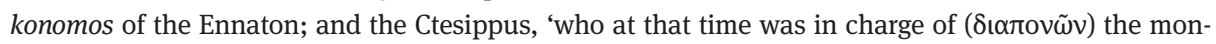
asteries of the Ennaton' who appears in the dependents of Moschus's and Sophronius's Life of John the Almsgiver: Anonymous Life of John the Almsgiver 9 ed. H. Delehaye, "Une Vie inédite de Saint Jean l'Aumonier," Analecta Bollandiana 45, 1927, 19-25, at 23; Epitome of the Life of John the Almsgiver 9 ed. E. Lappa-Zizicas, “Un épitomé de la Vie de S. Jean l'Aumônier par Jean et Sophronius,” Analecta Bollandiana 88, 1970, 265-78, at 276. This cannot be explained as a Chalcedonian takeover of the complex. For anti-Chalcedonians in the Ennaton under John the Almsgiver, see e.g. W. H. P. Hatch, "The Subscription in the Chester Beatty Manuscript of the Harclean Gospels," Harvard Theological Review 30, 1937, 141-55, at 149-54, placing Thomas of Harqel at the Monastery of the Antonians at the Ennaton, 'in the year 927 of Alexander, in the fourth indiction,' that is, at some point between October 615 and August 616; and the subscriptions to Paul of Tella's translations of Kingdoms 3-4, in P. de Lagarde, Bibliothecae Syriacae, Göttingen 1892, 222 n. 54 (from BM Add. 14437 fol. 122) and 256 (from BN Syr. 27 fol. 90), placing him in the same monastery in A.G. 927-928, fourth to fifth indiction $(=615 / 6-616 / 7)$. Both Thomas and Paul were adherents of the anti-Chalcedonian Antiochene patriarch Athanasius the Camel-driver, and seem to have participated with him in the Alexandria-Antiochene union of 617; see Michael the Great, Chronicle 10.26 (ed. Chabot vol. 4 399). For discussion cf. E. Wipszycka, The Alexandrian Church: People and Institutions, Warsaw 2015, 433-434, who also argues for a range of doctrinal opinions within the Ennaton complex, rather than its oscillation between doctrinal camps.

43 Justinian, Letter to the Alexandrian Monks (CPG 6878) ed. E. Schwartz, Drei dogmatische Schriften Justinians, Munich 1939, 5-43, at 7. 
menical Council (553) - at which all the patriarchs were accompanied by a small percentage of their bishops - nine Egyptian bishops are listed as attending, and belong to sees spread throughout the patriarchate, including the Thebaid..$^{44}$ It is demonstrable, in fact, that these persons do not represent the full cohort of Chalcedonian bishops - one, Theodore of Leontopolis, also appears in the Spiritual Meadow of John Moschus (c.630), where he is said to have been consecrated alongside two others, not present at the council. ${ }^{45}$ All this suggests, therefore, a significant and extensive presence in Egypt of pro-Chalcedonian bishops.

Could it be, as Maspero once suggested, that these appointments of Apollinarius were mere titulars, who never resided in their actual sees? ${ }^{46}$ The thesis depends upon the notion that a rabid, monolithic opposition to Chalcedon was entrenched among the general population, and although it seems clear that some monasteries were bastions against the council, and would later provide the personnel for the Severan episcopate, there is little to no evidence for the doctrinal convictions of the average Christian. For this same reason, speculations on, or assumptions about, the extent to which anti-Chalcedonism of some sort was and remained embedded amongst the wider population - a phenomenon for which there must have been considerable variation over time and space, and according to circumstance - seem otiose..$^{47}$ Moreover, as we shall see below, evidence to which Maspero did not have access does in fact suggest a massive depletion of the Severan episcopate in the period from 536-575. It is improbable, for both pastoral and for economic reasons, that the Chalcedonian patriarchs allowed these sees to sit vacant. We must suppose, then, that the attested depletion of Severan bishops was inverse to a concomitant expansion of those who accepted Chalcedon.

\section{Towards the New Church}

The doctrinal accommodation evidenced at the Ennaton is symptomatic of the doctrinal sea change which, as we shall see, was then occurring within the Egyptian episcopate. The situation was no doubt exacerbated in the evident reluctance of

44 See the episcopal list in Acts of the Fifth Ecumenical Council ed. E. Schwartz - J. Straub, Concilium universale Constantinopolitanum sub Iustiniano habitum, ACO 4.1, 2 vols, Berlin 1914-1971, vol. 1, 20-24. These are Sergius of Kynopolis (no. 64), Stephanus of Klysma (70), Bassus of Tamiathis (76), Theodore of Leontopolis (80), Aemilianus of Antipyrgus (81), George of Ptolemais (84), Elias of Diokletianopolis (88), Theonas of Kussa (89), and Procopius of Antinoe (120). Note also that John of Ephesus, Ecclesiastical History 3.4.6 refers to Chalcedonian bishops in the Thebaid in 542. 45 Moschus, Spiritual Meadow 124, naming Zosimus of Babylon, and two bishops, Paul and Theodore, for one or other of Leontopolis and Heliopolis. From the Acts of the Fifth Council (previous note) we can surmise that Theodore was bishop of Leontopolis, and Paul bishop of Heliopolis. Moschus claims that these three were ascetics from Cilicia, Melitene, and Galatia.

46 Maspero, Histoire des patriarches (cf. n. 6) 164, 177.

47 Pace e.g. Maspero, Histoire des patriarches (cf. n. 6) 177, 265. 
an exiled Theodosius to appoint new bishops to his province. Whether he had approved of Jacob Baradeus's efforts to do so elsewhere within the east is open to some doubt, ${ }^{48}$ but in 564 , almost three decades after his initial exile, he at last acted to establish a small episcopate. John of Ephesus's Lives of the Eastern Saints reports that, following the initial consecrations carried out through Jacob (c.553566), Theodosius then ordered the ordination of 'twelve bishops all at the same time in the royal city, for various cities of the Thebaid and of Egypt, besides many clergy, in as much as the patriarch Theodosius did not assent to the ordination of priests after he had left his see. ${ }^{49}$ John does not comment further on the details, but the plan was anticipated in Theodosius's appointment of a trusted confidante to the vacant throne of Antioch. The patriarch Sergius of Tella, whom Jacob had appointed in $c .557$, had died in c.560, but in 564 Theodosius instructed Jacob to appoint as Sergius's successor his own syncellus Paul of Beth Ukkame ('the Black'), an Alexandrian. ${ }^{50}$

In $c .565$ Theodosius then commissioned Paul to execute his plan. ${ }^{51}$ Five letters connected to the mission are embedded in the so-called Documenta ad origines monophysitarum illustrandas, a remarkable dossier, now extant in Syriac, of fortyfive letters written in the period from 535 to $c .580 . .^{52}$ In the first of these five letters Theodosius commissions the Antiochene patriarch Paul to appoint (his apocrisiarius) Longinus as bishop of the Nubians, ${ }^{53}$ but also refers to irregular ordinations which have occurred at the lower clerical levels in Alexandria, and instructs Paul to act as he sees fit. In the second, also sent to Paul, Theodosius speaks of the removal of the orthodox from their sees through persecution, and the danger that some will be deprived of a priest, and instructs the recipient to lead some eastern bishops

48 John of Ephesus, Lives of the Eastern Saints (ed. Brooks PO 18 697; PO 19 155-156) reports that Jacob did not find the requisite number of bishops in Constantinople to perform his first consecrations, which were instead carried out in Alexandria - this might therefore indicate the resistance of Theodosius (so Van Roey, “Les débuts” [cf. n. 14] 357-358).

49 John of Ephesus, Lives of the Eastern Saints (ed. Brooks PO 19 157). See also Michael the Great, Chronicle 9.30 (ed. Chabot vol. 4 314), Chronicle to 1234 ed. J.-B. Chabot, Chronicon anonymum ad annum Christi 1234 pertinens, CSCO 81-82, 2 vols, Louvain 1916-1920, vol. 2, 242, in which Theodosius is said to refuse the appointment of Athanasius on the basis that he would not make ordinations outside of his see (which would violate the canons).

50 See Documenta no. 9 ed. and trans. J.-B. Chabot Documenta ad origines monophysitarum illustrandas, 2 vols, CSCO 17 and 103, Paris 1907-1933, vol. 1, 89-90; John of Ephesus, Lives of the Eastern Saints (ed. Brooks PO 18 689-690; PO 19 157); with E. W. Brooks, "The Patriarch Paul” (cf. n. 18) 469-470.

51 I.e. between the consecration of Paul (564) and the death of Theodosius (566).

52 Cf. n. 50 above. For analysis of the dossier and summary of its contents see A. van Roey and P. Allen, Monophysite Texts of the Sixth Century, Leuven 1994, 267-303. I cite the documents according to the numbers which van Roey and Allen propose therein. See also P. Allen, "Religious Conflict between Antioch and Alexandria c. 565-630 CE," in W. Mayer - B. Neil (eds.), Religious Conflict from Early Christianity to the Rise of Islam, Berlin 2013, 187-199, esp. 191-196.

53 On Longinus see Honigmann, Évêques (cf. n. 5) 224-229. 
to Alexandria, there to perform ordinations. Here Theodosius promises Paul the assistance of the bishops John, Leonidas, and Joseph - the first and third of whom are the bishops of Cellia and Metelis (in the northwestern Delta), as we ascertain from their appearance elsewhere in the dossier. ${ }^{54}$ These three are indeed the addressees of the third letter, in which Theodosius informs them of Paul's mission to appoint bishops to destitute sees, and tells them that he has also written to the bishop Theodore (of Philae) ) $^{55}$ and to the archimandrites and people of Arcadia and the Thebaid and to the clerics, monks, and people of Alexandria. These constitute the fourth and fifth letters. ${ }^{56}$ In the latter Theodosius informs the Alexandrians that he had hoped to return in person, but now that old age and illness are upon him, and with orthodox bishops established throughout the east, he has appointed Paul and certain eastern bishops to perform episcopal consecrations. He reminds his recipients that he has before appointed certain bishops, and that he has also written to them to solicit their help. This seems to indicate, therefore, that Theodosius had appointed John, Leonidas, and Joseph during his exile (or perhaps before it?); but also that there were in 565 a mere four Egyptian bishops in communion with him: John of Cellia, Joseph of Metelis, Theodore of Philae, and the otherwise unknown Leonidas. ${ }^{57}$

In later sources there is no suggestion that John of Ephesus's reported twelve bishops were ever elected, perhaps because Theodosius's death in 566 had removed Paul's mandate. But how had Theodosius come to his sudden change of heart? Old age, illness, and the realisation that he would not return are one potential explanation; another is the rise and spread within Severan circles of tritheism (the belief that the three divine persons also have three individual essences, associated with the bishops Conon of Tarsus and Eugenius of Seleucia, and then with the Alexandrian philosopher John Philoponus). ${ }^{58}$ From his exile in Constantinople Theodosius had

54 The sees of John of Cellia ( $q$ lyt') and Joseph of Metelis (mțl'ws) are referred to in Documenta no. 42 (Chabot vol. 1 273). It is possible that it was these two who, along with Jacob Baradeus, consecrated Conon of Tarsus and Eugenius of Seleucia at Alexandria; see John of Ephesus, Lives of the Eastern Saints (ed. Brooks PO 18 697; PO 19 156).

55 On the anti-Chalcedonian bishop Theodore (c.525-577), who was consecrated under Timothy IV, and who is known also through several inscriptions (I.Philae II 200, 202-204, 216) see J. H. F. Dijkstra, Philae and the End of Ancient Egyptian Religion: A Regional Study of Religious Transformation (289642 CE), Leuven 2008, 305-338.

56 Documenta nos. 18-22. Note that the Egyptian bishop John of Pelusium was resident in Constantinople and was one of the signatories to the same documents.

57 See also Honigmann, Évêques (cf. n. 5) 175; E. Wipszycka, "Les élections épiscopales en Égypte aux VI'-VII siècles,” in J. Leemans et al. (eds.), Episcopal Elections in Late Antiquity, Berlin 2011, 259-291, at 271 (also ead., Alexandrian Church [cf. n. 42] 145).

58 On tritheism see A. van Roey, "La controverse trithéite depuis la condemnation de Conon et Eugène jusqu'à la conversion de l'évêque Elie,” in W. C. Delsman et al. (eds.), Von Kanaan bis Kerala. Festschrift für Prof. Mag. Dr. Dr. J.P.M. van der Ploeg O.P. zur Vollendung des siebzigsten Lebensjahres am 4. Juli 1979, Kevelaer 1981, 487-497; id., "La controverse trithéite jusqu'à l'excommunication de Conon et d'Eugène (557-569)," Orientalia Lovaniensia Periodica 16, 1985, 141-65; R. Y. Ebied et al., Peter of Callinicum: Anti-Tritheist Dossier, Leuven 1981, 20-33; van Roey and Allen, Monophysite 
denounced the doctrine, and it is possible that the irregular ordinations to which he refers in his letter of commission to Paul indicate tritheist inroads at Alexandria. ${ }^{59}$

In 565 there might, however, have been a more pressing problem. In late 564 it appears that the emperor Justinian had issued an edict which adopted the aphthartist belief in the incorruptibility of Christ's body, and although this doctrine did not necessitate the abandonment of Chalcedon - and had some evident appeal among certain Chalcedonian theologians of the time - its official recognition must have represented an attempt to realise a rapprochement with the Julianists, for whom it was their central teaching. ${ }^{60}$ In Alexandria the effects of that recognition are palpable. Under AM 6057 (564/5), Theophanes's Chronographia first reports Justinian's edict recognising aphthartism, and then records his subsequent death, in November 565; but it then continues to report that, 'In the same year Theodosians and Gaianites

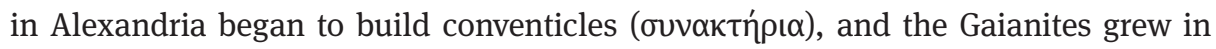
power and ordained their archdeacon Elpidius as bishop for themselves. ${ }^{61}$ According to the Chronographia, the emperor then ordered Elpidius to be arrested and brought to the capital. There is no suggestion, then, that Justinian would now tolerate the establishment of Gaianite bishops. But his acceptance of aphthartism nevertheless seems to have given the Gaianites a new confidence, and precipitated their attempts to appoint a new hierarch. ${ }^{62}$ We can imagine that in such a context, the exiled The-

Texts (cf. n. 52) 105-143; Grillmeier - Hainthaler, Christ in Christian Tradition (cf. n. 10) vol. 2, pt. 3, 268-280; On Philoponus see esp. ibid. vol. 2 pt. 4 107-146; U. M. Lang, John Philoponus and the Controversies over Chalcedon in the Sixth Century: A Study and Translation of the Arbiter, Leuven 2001. Lang reasserts (convincingly) the patristic and Christological, rather than the Aristotelian and philosophical, basis of Philoponus's position.

59 So Brooks, “The Patriarch Paul” (cf. n. 18) 470. For Theodosius's anti-tritheism see his letter at Documenta no. 5, with van Roey and Allen, Monophysite Texts (cf. n. 52) 131-138. In his appointment of Paul Theodosius might well have been mindful also of the good relations which had existed between Sergius of Tella and John Philoponus, who dedicated his De opificio mundi to the former as patriarch (and to the tritheist Athanasius); see L. S. B. MacCoull, "The Historical Context of John Philoponus' De opificio mundi in the Culture of Byzantine-Coptic Egypt," Zeitschrift für antikes Christentum 9, 2006, 397-423, esp. 411-413. On Sergius's tritheist leanings cf. Honigmann, Évêques (cf. n. 5) $192-195$.

60 For Justinian's adoption of aphthartism see, in addition to Theophanes below, Eustratius Presbyter, Life of Eutychius 33-34 ed. C. Laga, Vita Eutychii Patriarchae Constantinopolitani, CCSG 25, Turnhout 1992; Evagrius Scholasticus, Ecclesiastical History 4.39 ed. J. Bidez and L. Parmentier, The Ecclesiastical History of Evagrius with the Scholia, London 1898; Michael the Great, Chronicle 9.34 (ed. Chabot vol. 2 325-326); Chronicle of Zuqnin (ed. Chabot vol. 2 144). For analysis see Grillmeier Hainthaler, Christ in Christian Tradition (cf. n. 10) vol. 2, pt. 2, 467-473; K.-H. Uthemann, "Kaiser Justinian als Kirchenpolitiker und Theologe," Augustinianum 39, 1999, 5-84; Kofsky, "Julianism” (cf. n. 10) $278-285$.

61 Theophanes, Chronographia AM 6057 ed. C. de Boor, Theophanis Chronographia, Leipzig 1883, $240-241$.

62 It is not clear if Gaianus himself was dead at this point. John of Nikiu, Chronicle 92 states that Gaianus died in exile before Theodosius (566), but the precise date is unclear. 
odosius might well have been prompted to secure the dwindling Severan episcopate which he had so long neglected.

Theophanes's subsequent evidence is more difficult to understand. The same notice reporting the appointment and arrest of Elpidius continues: 'In secret and at night, the Theodosians ordained as bishop for themselves Dorotheus. And through coming together as one, the Gaianites and the Theodosians enthroned a common bishop for themselves. ${ }^{63}$ Maspero wished to see in this Dorotheus a Severan successor to Theodosius, elected after the latter's death in the summer of $566 ;^{64}$ but he was therefore forced to differentiate him from the Dorotheus whom John of Ephesus, writing in 580/1, claims was contemporaneous bishop of the Gaianites, and had been for 'many years' - Sophronius of Jerusalem, writing in 634, also calls Dorotheus a Gaianite. ${ }^{65}$ Given the coincidence of names, it seems probable that these persons are in fact identical, and that Dorotheus was a Gaianite who effected a union of Severan and Julianist factions following Justinian's aphthartist edict. That all Severans, and all Julianists, were complicit in this union seems improbable; but for some anti-Chalcedonians at least, it seems that Dorotheus served as the bishop, and thus patriarch, of Alexandria. When this occurred is not explicit, but since Justinian was able to counteract the election of Elpidius, but not of Dorotheus, it is perhaps not unreasonable to suppose that it occurred after the emperor's death in late 565, and that in this shared appointment the Gaianites and Theodosians hoped to exploit the change of regime in Constantinople.

Dorotheus is perhaps also identical, therefore, with the unnamed Gaianite patriarch who Michael the Great's Chronicle suggests to have assumed his position before the death of Theodosius, and to have then appointed numerous bishops throughout Egypt. ${ }^{66}$ Reconstructing the extent and duration of this reported episcopate - which occurred at around the same time as the union of the Theodosians and the Gaianites, and is in all likelihood a product of it - is crucial to appreciating the situation after 565 , but we have no further evidence. No extant anti-Chalcedonian source (all written from a later, Severan perspective) has an interest in describing a union of Theodosians and Gaianites, or the extent of its success. If the anti-Chalcedonians united under Dorotheus had hoped, however, that the new emperor Justin II might prove more amenable to their cause, then that hope was soon quashed. In the subsequent notice in the Chronographia (AM 6058) - and thus in clear connection with the account of Dorotheus's union, and no doubt drawing from the same source - Theophanes re-

63 Theophanes, Chronographia AM 6057. Cf. John of Ephesus, Ecclesiastical History 3.1.40.

64 Maspero, Histoire des patriarches (cf. n. 6) 214-216, 223, 232 (and arguing that this Dorotheus died in c.570).

65 John of Ephesus, Ecclesiastical History 3.1.40 (with J. J. van Ginkel, John of Ephesus: A Monophysite Historian in Sixth-Century Byzantium, unpublished PhD thesis, Gronigen 1995, 73 for the date); Sophronius, Synodical Letter 2.6.1 ed. R. Riedinger, Concilium Universale Constantinopolitanum Tertium, Acta Conciliorum Oecumenicorum ser. 2, vol. 2.1, Berlin 1990, $410-494$.

66 See Michael the Great, Chronicle 9.31 (ed. Chabot vol. 4 321-322). 
ports Justin's dispatch to Egypt of one 'abba Photinus' (i.e. Photius, the stepson of Belisarius), ${ }^{67}$ 'giving him authority over every person and affair, in order to pacify

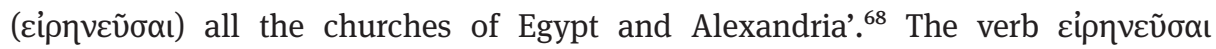
would seem to indicate the suppression of rebellion, and an obvious explanation for this remarkable, wide-ranging mission would be the anti-Chalcedonian ordinations alleged in Michael's Chronicle. Although Photius's mission seems to have suppressed the new initiative, this pattern - of an anti-Chalcedonian attempt, in the context of a change of regime, to create a new church - will be repeated in the next decade, and with far greater success.

If Theophanes is correct in placing Photius's mission in the first year of Justin, then it must have occurred around the death of the exiled Theodosius in July 566. After that death the situation is even more uncertain. Dorotheus, as we have seen, remained on the scene until 580/1, when John of Ephesus calls him the bishop of the Gaianites. But how long did his reported union endure? In later Severan sources the nine years after Theodosius's death is presented as a patriarchal interregnum (the History of the Patriarchs, in fact, attempts to efface the same gap altogether). ${ }^{69}$ We are told in the Chronicle of Michael, moreover, that after the death of Theodosius, Paul of Beth Ukkame agitated, without success, to replace his former master as Alexandrian patriarch; ${ }^{70}$ and in the same source we have conflicting reports of an attempted appointment to the same position of the tritheist Athanasius, nephew of the empress Theodora. ${ }^{71}$ All this might suggest, therefore, that Theodosius's throne was perceived to be vacant from 566, and that the Theodosians' recognition of Dorotheus dissolved with the mission of Photius. But it should be remembered that none of the aspirants to the patriarchal throne would have an interest in recognising the claim of Dorotheus; nor should we expect our extant (Severan) sources to describe the union over which he presided.

In the summer of 575, at least, it is clear that some prominent Severan clerics did not recognise Dorotheus. At this point, according to John of Ephesus, the archpriest and archdeacon at Alexandria, Theodosius and Theodore, invited Longinus of Nubia to seek out and to consecrate a new patriarch. ${ }^{72}$ John's evidence indicates that a hi-

\footnotetext{
67 See PLRE III Photius 2.

68 Theophanes, Chronographia AM 6058 (ed. de Boor 242).

69 Documenta no. 42 (ed. Chabot vol. 1 271) and John of Ephesus, Ecclesiastical History 3.4.8 put the gap at nine years; ibid. 3.4.12 at ten (followed in Chronicle to 1234 [ed. Chabot vol. 2 243-244]). The History of the Patriarchs extends the tenures of Theodosius and Damian in order to close the gap. 70 See Michael the Great, Chronicle 10.1 (ed. Chabot vol. 4 333), Chronicle to 1234 (ed. Chabot vol. 2 242-243).
}

71 In Michael the Great, Chronicle 10.1 (ed. Chabot vol. 4 333), and Chronicle to 1234 (ed. Chabot vol. 2 242-243), it is said that the Alexandrians preferred Athanasius to Paul. But at Michael the Great, Chronicle 9.30 (ed. Chabot vol. 4 314-315), we read that the emperor (Justin) wished to appoint Athanasius to replace Theodosius, but that the Alexandrians resisted.

72 John of Ephesus, Ecclesiastical History 3.4.10. The precise meaning of the letter to Longinus (CPG 7223) was later disputed, however; see Documenta no. 42 (ed. Chabot vol. 1270 - 277); L. Lontie, "Une 
erarchy of Severan clerics remained in Alexandria - their numbers were no doubt easier to maintain, since clerics depended on the existence of a single Severan bishop, such as John of Cellia or Joseph of Metelis, to ordain them. But we do not know how many clerics Theodosius and Theodore represented, what communities they served, and to what extent Severan priests were able to resist the advance of the Chalcedonian episcopate outside of Alexandria.

A precious citation from the archdeacon Theodore's letter to Longinus - quoted within a pro-Paulianist treatise of the Nicaean hermit Sergius, now embedded in the aforementioned Documenta - demonstrates that the contemporaneous doctrinal scene at Alexandria was even more complex than we could have imagined on the basis of other sources, and introduces us to another crucial if ambiguous character: Clementinus. Therein Theodore appeals for Longinus's intervention with the observation that, '[P]eople are now going over to Epiphanius, who belongs to the faction of Eusebius, which is opposed to the faction of Paul the Black, and they have ministered together with Clementinus, beyond the counsel of all the church ... Moreover, they have made him perform ordinations. All these things have happened because we do not have an archbishop.' The same quotation from Theodore's letter then turns to two of those four Severan bishops who, as we saw above, had remained in communion with Theodosius up to 565. It reports that the bishop Joseph of Metelis had refused to co-operate with his colleague John of Cellia in the performance of a patriarchal consecration. ${ }^{73}$ Soon after in his treatise Sergius suggests an explanation for this discord: that John 'had participated in the ministration together with those who received ordination from Clementinus. ${ }^{74}$

Who was this Clementinus? The anti-Paulianist 'Epiphanius' and 'Eusebius' with whom he is here associated are otherwise unknown, but the same treatise of Sergius provides two further substantive comments on him. It reports that during Theodosius's lifetime, and even after his death, this Clementinus was not able to obtain ordination to the Alexandrian church, but 'now' is 'head of the see ... of the legitimate congregation of Alexandria,' as demonstrated in the subscription to the letters which he once sent to Paul from Alexandria. ${ }^{75}$ Sergius wrote his letter in $580,{ }^{76}$ meaning that Clementinus was active into the patriarchate of Damian. What then does it mean that he is head of the 'legitimate' congregation? Amongst those that disapprove of Clementinus we can count the patriarch Theodosius, Joseph of Metelis, the archdeacon Theodore, and the hermit Sergius, all of whom were Severans of some sort. But that Sergius calls him 'legitimate', and that John of Cellia co-operates

traité syriaque jacobite contre les partisans de Paul de Bēth Ukkāmē (564-581) (ms. British Library Ad. 14.533f. 172r-b-176v-b),” Orientalia Christiana Periodica 63, 1997, 5-51, at 24-26.

73 Documenta no. 42 (ed. Chabot vol. 1273 ).

74 Documenta no. 42 (ed. Chabot vol. 1276 ).

75 Documenta no. 42 (ed. Chabot vol. 1 276, and again on 277).

76 Documenta no. 42 (ed. Chabot vol. 1 278) refers to the Alexandrians' recent meeting in Constantinople (March 580). 
with his clerics, must mean that Clementinus too was a Severan, even if one whom some co-confessionalists considered illegitimate. ${ }^{77}$ It seems, therefore, that Clementinus too claimed the mantle of Theodosius.

It is perhaps telling, therefore, that John of Cellia did not participate in Longinus's subsequent appointment of a new patriarch. ${ }^{78}$ In league with two eastern bishops, ${ }^{79}$ and with the approval of Paul the Black and Theodore of Philae, Longinus now ordained as patriarch one Theodore of Rhamnis, a Syrian archimandrite at Scetis. ${ }^{80}$ Under pressure, John of Cellia then wrote to Longinus approving his action, promising not to act against it, and renouncing Clementinus as an illegitimate impostor (since Longinus and Theodore of Philae had, John claims, denounced him). ${ }^{81}$ The Severans at Alexandria, however, resented Paul's perceived interference, and six weeks later appointed their own Severan patriarch, Peter, a deacon who had once been in exile with Theodosius. ${ }^{82}$ John of Cellia, ever the chameleon, was one of the consecrating bishops; ${ }^{83}$ but in order to effect the appointment the Alexandrians, like Longinus, also had recourse to two Syrian bishops. ${ }^{84}$ The rival patriarchal ap-

77 Pace Brooks, “The Patriarch Paul” (cf. n. 18) 471-472, who regards Clementinus a tritheist patriarch. This is improbable since in 567 (Honigmann, Évêques [cf. n. 5] 183) John of Cellia seems to have presided over a condemnation of the tritheist Philoponus in Alexandria; see Documenta nos. 25 (ed. Chabot vol. 1 151), 28.

78 Nor did Joseph of Metelis participate, according to Sergius; but he was ill and died soon after the consecration: Documenta no. 42 (ed. Chabot vol. 1 278).

79 Brooks, "The Patriarch Paul” (cf. n. 18) 471 and Honigmann, Évêques (cf. n. 5) 232-237 identify these bishops as John of Chalcis and George 'of the Ourtaye' in Armenia (cf. John of Ephesus, Lives of the Eastern Saints [ed. Brooks PO 19 156, 212]).

80 See John of Ephesus, Ecclesiastical History 3.1.40, 4.10 (repeated in Michael the Great, Chronicle 10.12), calling Theodore a Syrian and archimandrite 'in the desert of the hermits, beyond the blessed Mar Minas, [at] a place called Rhamnis.' H. G. Evelyn White, The Monasteries of the Wâdi 'n Natrûn II: The History of the Monasteries of Nitria and of Scetis, New York 1932, 319-320 suggests that he might be identical with the archimandrite Theodore who seems to preside over a community of Syrians at Scetis in July A.G. 887 (576), as revealed in a note within a Syriac codex (Vat. Syr. 142).

81 The letter (CPG 7230) is extracted in Documenta no. 42 (ed. Chabot vol. 1277-278), in response to an accusation that John and Joseph had not approved Theodore's consecration (ibid. 229, 270). Nevertheless the meaning of John's approval was much debated; see Lontie, "Une traité syriaque jacobite" (cf. n. 72) 24, 30.

82 John of Ephesus, Ecclesiastical History 3.4.11 (Michael the Great, Chronicle 10.12 for the same; also Chronicle to 1234 [ed. Chabot vol. 2 243-245]). For the possible dates of Theodore's and Peter's consecrations ( $23^{\text {rd }}$ June and August $4^{\text {th }} 575$ ) see Brooks, “The Patriarch Paul” (cf. n. 18) 474 n. 4 - but note that he confuses the evidence of the Chronicon Orientale.

83 Documenta no. 42 (ed. Chabot vol. 1 272, 279). John of Ephesus, Ecclesiastical History 3.4.11 suggests that the 'bishop John' who consecrated Peter was awaiting trial for some 'canonical offence'. Although John of Ephesus is invested in an evident attempt to discredit Peter, it is possible that this offence was collaboration with Clementinus's clerics.

84 John of Ephesus, Ecclesiastical History 3.4.11 (note that the quotation from ibid. 3.4.12 in Chronicle to 1234 [ed. Chabot vol. 2 244] has an additional sentence claiming there were but two consecrators it is possible that this is original to John, since he regarded John of Cellia as excommunicate; cf. the previous note). The Syrian bishops were both called 'Antoninus' and were consecrated after 566; cf. 
pointments, therefore, both depended on Syrian support to meet the requirement of the canons that three bishops preside over the consecration of a new patriarch. Without such support, the Severan episcopate - its numbers now at a nadir, and its few remaining members beset with infighting - might well have faced extinction.

\section{The Making of the Severan Episcopate}

Thus far we have reconstructed the dramatic decline of the Severan episcopate following Theodosius's exile, the perhaps failed attempts of the Gaianite Dorotheus to appoint an anti-Chalcedonian episcopate, and the series of competing patriarchal claimants who emerged in the decade following Theodosius's death. But with the Alexandrians' appointment of Peter this picture changes, and one perceives the first germs of the Severan church proper. The actions of Peter, like those of Jacob Baradeus further east, brought the Severan episcopate back from the brink of annihilation. But where Jacob had restricted himself to a small number of appointments, Peter would create something which resembled a true rival church. ${ }^{85}$

John of Ephesus makes the startling claim that upon his consecration, Peter appointed either seventy or eighty bishops throughout Egypt. ${ }^{86}$ It should be remembered that John demonstrates an intense dislike both for Peter and the Alexandrians, which might well have prompted him to exaggerate the scale of the perceived abuse. ${ }^{87}$ But if the number is accurate, this must mean almost all of the province's bishoprics. There is no need to suppose that these were sees which were vacant. ${ }^{88}$ As has been said above, it seems improbable that the Chalcedonian patriarchs would have allowed a mass of thrones to go vacant, and under Apollinarius we can name the Chalcedonian incumbents of various sees spread throughout the patriarchate. Rather, this is a new church, established as a rival to its Chalcedonian equivalent. The precise mechanisms through which this was achieved are unclear, and none of Peter's bishops can be named with confidence. John of Ephesus derides

Documenta no. 42 (ed. Chabot vol. 1 269, 272, 279), and Lontie, “Une traité syriaque jacobite” (cf. n. 72) 18, with Honigmann, Évêques (cf. n. 5) 238.

85 See also Wipszycka, "Les élections épiscopales” (cf. n. 57) 267 (and ead., Alexandrian Church [cf. n. 42] 122-123, $140-141)$.

86 John of Ephesus, Third Part of the Ecclesiastical History 1.40 (claiming eighty), 4.12, 4.16 (all seventy).

87 Cf. Wipszycka, "Les élections épiscopales” (cf. n. 57) 266-267, who suggests that the number is 'volontairement exagéré' in order to emphasise the absurdity of the situation, but is nevertheless willing to accept that Peter had indeed ordained bishops for 'la quasi totalité des dioceses' (the same points in ead., Alexandrian Church [cf. n. 42] 140-141).

88 Cf. above p. 160. Note that the citation from John of Ephesus, Ecclesiastical History 3.4.12 in Chronicle to 1234 (ed. Chabot vol. 2 244) has an additional statement regarding these bishops: 'Many of these were without dioceses.' This means, perhaps, that their dioceses were titular, because of Chalcedonian incumbents. Is the statement original to John? 
the calibre of recruits chosen with such haste, although he does not comment on their origins. But we can perhaps presume that the new bishops came from the remaining communities of lower order Severan clerics, and from the monasteries.

Although evidence for Peter's patriarchate is wanting, the existence of the new Severan church is nevertheless demonstrated in an unprecedented explosion of material which witnesses the activities of the dependants of Peter's successor Damian (several of whom had monastic backgrounds). ${ }^{89}$ This evidence includes a large number of Greek and Coptic documents, some artefacts, and a considerable number of hagiographies, homilies, and treatises still extant in Coptic and Copto-Arabic. From this diverse material, moreover, we can name the specific sees of a remarkable number of Severan bishops active under, or soon after, Damian: for example, John of Paralos; Nicholas and John of Hermopolis; Senuthes of Antinoe; Constantine of Assiut; Rufus of Shotep; Abraham of Diospolis; Pesynthius and Moses of Koptos; Pisrael of Qus; Joseph of Apollinopolis Parva; Antonius of Ape; and Abraham, Moses, and Pesynthius of Hermonthis. Elsewhere I have discussed in detail the extent, contents, and significance of this evidence; but suffice to note here that such evidence provides an eloquent testament to the sudden existence and assertiveness of the new church, with known incumbents stretching from the Mediterranean to the Thebaid. ${ }^{90}$

Were the secular authorities powerless to prevent this process? It has been argued above that the accession of Justin II witnessed an attempt - under the leadership of the Gaianite Dorotheus - to create a new episcopate, and that this attempt was thwarted through the dispatch of a mission under Photius. Indeed, from this perspective is striking that the initiative of the Severan clerics of Alexandria to appoint a new patriarch, in the summer of 575, follows on an effective change of regime in Constantinople, and with it the adoption of a more lenient doctrinal stance. Although he had moved to check the creation in Egypt of a rival hierarchy, in his earliest reign (from 565 to 571) Justin II had nevertheless attempted to reconcile anti-Chalcedonian theologians through doctrinal negotiation, but had then turned to persecution in the face of continued recalcitrance. ${ }^{91}$ In December 574, however, the emperor had begun to manifest the first signs of madness, and thus elevated the comes excubitorum Tiberius to Caesar, making him de facto emperor. ${ }^{92}$ It is possible, therefore, that the

89 E. g. Constantine of Assiut, Rufus of Shotep, Joseph of Apollonopolis Parva, Pesynthius of Koptos; for details see Booth, “A Circle of Egyptian Bishops” (cf. n. 7).

90 Ibid.

91 See John of Ephesus, Ecclesiastical History 3.1.1-30; Evagrius Scholasticus, Ecclesiastical History 5.4; and esp. Michael the Great, Chronicle 10.1-4; with Av. Cameron, "The Early Religious Policies of Justin II,” in D. Baker (ed.), The Orthodox Churches and the West, Studies in Church History 13, Oxford 1976, 51-67, esp. 62-65. Note also that John of Nikiu, Chronicle 94 (ed. Zotenberg 167) reports a persecution in Egypt after Justin's proclamation of the faith (sc. the so-called 'second Henotikon').

92 See John of Ephesus, Ecclesiastical History 3.3.2-5; Evagrius Scholasticus, Ecclesiastical History 5.13; Theophylact Simocatta, History 3.16.3-6 ed. C. de Boor and P. Wirth, Theophylacti Simocattae Historiae, Stuttgart 1972; Paschal Chronicle ed. L. Dindorf, Chronicon Paschale, Bonn 1832, 689; 
Severans sought to take advantage of the change in regime in the same manner that the Gaianites had a decade earlier. This would mean, in turn, that the anti-Chalcedonians in Egypt were eager to create their own episcopate, and that the imperial will was otherwise decisive in restraining them.

What is so striking, then, is that Tiberius did not suppress the new initiative. In anti-Chalcedonian sources, Tiberius's rule (as sole emperor from 578-582) is celebrated as a time of tolerance, ${ }^{93}$ and John of Ephesus twice ascribes to him a memorable retort - when the Constantinopolitan patriarch had pressed him to persecute the enemies of Chalcedon - to the effect that the empire's real enemies were not fellow Christians within, but barbarians without (later, John ascribes the same sentiment to Tiberius's successor Maurice [582-602]). ${ }^{94}$ Throughout his reign Tiberius was indeed preoccupied with the Persians, ${ }^{95}$ and in this context he might well have been unwilling to continue his predecessors' pursuit of the universal recognition of Chalcedon. Extant examples of Tiberius's intervention in ecclesiastical affairs are indeed few, ${ }^{96}$ and in his reign there are no attested councils aimed at the reconciliation of Chalcedonians and anti-Chalcedonians, in contrast to those of his predecessors. At the same time, in his apparent failure to interfere in internal anti-Chalcedonian affairs - such as Peter's reported consecrations - the emperor must have further encouraged the burgeoning discord between Jacobite, Paulianist, and Theodosian factions. Perhaps realising this, in 580 Tiberius at last attempted to resolve their differences. At the emperor's instigation, a grand but failed Severan conference was convened in Constantinople. ${ }^{97}$ But it is notable that even here it is the Christian Jafnid leader al-Mundhir who is allowed to assume the role of secular mediator, rather than the emperor himself. ${ }^{98}$

John of Nikiu, Chronicle 94 (ed. Zotenberg 167); Theophanes, Chronographia AM 6067. On Tiberius see PLRE III Tiberius Constantinus 1.

93 John of Ephesus, Ecclesiastical History 3.3.20 - 22; John of Nikiu, Chronicle 94 (ed. Zotenberg 167168). Cf. Evagrius Scholasticus, History 5.13; Theophylact Simocatta, History 3.16.3-6.

94 John of Ephesus, Ecclesiastical History 3.1.37; 3.12 (and cf. 3.20). Cf. also ibid. 3.3.13, 26 on Tiberius's (initial) tolerance for Arians. Maurice: ibid. 3.5.15, 21. Later (in 598/9) Maurice's nephew Domitian of Melitene launched a persecution: see Michael the Great, Chronicle 10.23, 25; Chronicle to 1234 82; Chronicle to 724 ed. E. W. Brooks, Chronica minora II, CSCO 3, Paris 1960, 75-156, at 145; Chronicle to 819 ed. A. Barsaum in Chabot (ed.), Chronicon anonymum ad 1234 (cf. n. 49) vol. 1, 3-22, at 10. 95 For a useful guide see G. Greatrex and S. Lieu, The Roman Frontier and the Persian Wars Part II: $A D$ 363-628, London 2002, 151-166.

96 See the arrest of Damian's clerics at n. 117 below. John of Ephesus, Ecclesiastical History 3.3.21 excuses Tiberius of a persecution effected in the capital c.581, and blames the patriarch Eutychius. 97 John of Ephesus, Ecclesiastical History 3.4.39-40.

98 For the long-standing Jafnid protection of Paul, and continuous efforts at rapprochement, see John of Ephesus, Ecclesiastical History 3.2.8, 4.21-22, 4.36, 4.39, 4.41-43; Michael the Great, Chronicle 10.12-13, 17; Documenta nos. 23, 39, 41, 42. For analysis see esp. R. G. Hoyland, "Late Roman Provincia Arabia, Monophysite Monks and Arab Tribes: A Problem of Centre and Periphery," Semitica et Classica 2, 2009, 117-39; G. Fisher, Between Empires: Arabs, Romans, and Sasanians in Late Antiquity, Oxford 2011, esp. 56-64; P. Wood, "Christianity and the Arabs in the Sixth Century," in G. Fisher - J. 
The emperor's relative disengagement from doctrinal politics had, then, sanctioned the establishment and subsequent existence of a Severan patriarch in Alexandria, and the creation of Severan bishoprics throughout the chora. From the Severan perspective, moreover, we must also wonder if that same disengagement encouraged the abandonment of hopes that the emperor might somehow be converted to the anti-Chalcedonian cause, ${ }^{99}$ and in turn the expectation that alternative patrons might be sought within the secular sphere. After the failure of the conference of 580 - which Damian in effect derailed ${ }^{100}$ - there is little evidence of contact between the court and the new Severan patriarchate, and it is possible that it was left more or less to its own devices, outside of imperial oversight. ${ }^{101}$ In his apparent acceptance of this process Tiberius had, in the short term, contributed to the proliferation of rival claimants, and of conflicts, within the broad Severan communion; but he had also therein given succour to the Severans in Egypt at a time when the Chalcedonian church was all but triumphant, and allowed the creation of an institution whose members soon set about entrenching themselves as rivals to their Chalcedonian equivalents.

\section{A Rural Episcopate}

The most dramatic aspect of Damian's patriarchate is no doubt his spectacular clash, from 586, with his Antiochene counterpart Peter of Callinicum. This clash has been detailed in several modern studies, and there is no need to repeat the details here. ${ }^{102}$ But suffice to note that in an important and compelling paper, Philippe Blaudeau has demonstrated that Damian's actions on the international stage in this period - which include an attempt to consecrate an (anti-Paulian) patriarch at Antioch, ${ }^{103}$ and the

Dijkstra (eds.), Inside and Out: Interactions between Rome and the Peoples on the Arabian and Egyptian Frontiers in Late Antiquity, Leuven 2014, 353-368, at 356-363.

99 As suggested in P. Blaudeau, "Le voyage de Damien d'Alexandrie vers Antioche puis Constantinople (579-580), motivations et objectifs," Orientalia Christiana Periodica 63, 1997, 333-361, at 357359.

100 See John of Ephesus, Ecclesiastical History 3.4.43, with Blaudeau, "Le voyage” (cf. n. 99) 351354.

101 Evidence for contact under Maurice exists in the title to Damian of Alexandria, On the Birth of Our Saviour ed. W. E. Crum, Theological Texts from the Coptic Papyri, Oxford 1913, 21-33, which places Maurice's praetorian prefect of the east in the audience. Note also that the Coptic and Arabic titles to Constantine of Assiut's Encomia on Claudius (c.600) place in the audience a high imperial official. Both are discussed in more detail in Booth, "A Circle of Egyptian Bishops" (cf. n. 7).

102 See esp. Ebied et al., Anti-Tritheist Dossier (cf. n. 58) 34-43; C. D. G. Müller, "Damian, Papst und Patriarch von Alexandrien," Oriens Christianus 70, 1986, 118-142; Blaudeau, "Le voyage” (cf. n. 99). 103 See the account in John of Ephesus, Ecclesiastical History 3.4.41, also Michael the Great, Chronicle 10.17 . 
performance of episcopal consecrations at Constantinople ${ }^{104}$ - were driven through a desire to present himself as the continuator of both Jacob Baradeus and Theodosius, and thus also as the spiritual leader of the Severan commonwealth. ${ }^{105}$ In the end, Damian's commitment to asserting the claims of his Alexandrian throne proved counter-productive. In 586 Peter denounced him as a heretic, and henceforth the horizons of the Severan patriarchs did not often extend outside their own provinces. But it should be remembered that, in a context of radical ecclesiological change, this development was not inevitable, and that in different circumstances the two emergent churches might well have coalesced into a single, anti-Chalcedonian commonwealth under the guidance of a senior, 'ecumenical' patriarch in the mould of Theodosius or Damian.

The domestic situation of Damian and his bishops has been more neglected, but here too one detects the ecclesiological experimentation evident in Damian's international activities. Opponents of Damian both Chalcedonian and anti-Chalcedonian delighted in describing the ever-expanding number of sects within Egypt, ${ }^{106}$ or in enumerating the competing claimants to the Alexandrian throne. ${ }^{107}$ At Alexandria, scattered references indeed lend the impression of a complex doctrinal scene, in which Damian's Theodosians existed alongside numerous anti-Chalcedonian factions and their leaders (Gaianites, Tritheists, Agnoetae, Niobites, etc). ${ }^{108}$ These need not detain us here. ${ }^{109}$ But let us note that - in contrast to the rich evidence which exists for Damian's bishops in the chora - it is difficult if not impossible to know how far such divisions extended outside the febrile intellectual atmosphere

104 John of Ephesus, Ecclesiastical History 3.4.41, with Honigmann, Évêques (cf. n. 5) 241-243; Blaudeau, "Le voyage” (cf. n. 99) 349-350.

105 Blaudeau, "Le voyage" (cf. n. 99) 343-354.

106 Timothy of Constantinople, On the Reception of Heretics (ed. PG 86, here 41B-45C). The text contains two lists of anti-Chalcedonian heretics, one of which names Damian as leader of the Theodosians, suggesting it was composed in his lifetime.

107 John of Ephesus, Ecclesiastical History 3.4.44, speaking of three anti-Chalcedonian patriarchs (sc. Damian, Theodore of Rhamnis, Dorotheus). He does not seem to know of Clementinus.

108 See above n. 106. Embassies to Damian of tritheists: John of Ephesus, Ecclesiastical History 3.5.9; Anti-Tritheist Dossier (ed. Ebied et al. 58); Michael the Great, Chronicle 10.22. Clash with Stephanus the Sophist: Dionysius of Tel Mahre ed. J.-B. Chabot in E. W. Brooks, Historia ecclesiastica Zachariae Rhetori vulgo adscripta, CSCO 84, Paris 1921, 219-224; used in Michael the Great, Chronicle 10.21 and Chronicle to 1234 (ed. Chabot vol. 2 259). On Stephanus see the conflicting positions in W. WolskaConus, "Stéphanos d'Athènes et Stéphanos d'Alexandrie. Essai d'identification et de biographie," Revue des études byzantines 47, 1989, 5-89; K.-H. Uthemann, "Stephanos von Alexandrien und die Konversion des Jakobiten Probos, des späteren Metropoliten von Chalkedon: ein Beitrag zur Rolle der Philosophie in der Kontroverstheologie des 6. Jahrhunderts,” in C. Laga et al., After Chalcedon: Studies in Theology and Church History Offered to Professor Albert Van Roey for His Seventieth Birthday, Leuven 1985, 381-399.

109 Cf. the accounts in Maspero, Histoire des patriarches (cf. n. 6) 290 - 295; Müller, "Damian, Papst” (cf. n. 102) 123-125. 
of Alexandria. ${ }^{110}$ Although the absence of actual Gaianite sources makes a detailed picture impossible, Gaianism seems to have remained strong within and long after Damian's lifetime. ${ }^{111}$ But the others, one suspects, were minor concerns.

Damian's defining relationship was, no doubt, with the Chalcedonian patriarchs John IV (569/570 - 580) and Eulogius (581-607/608). ${ }^{112}$ Peter IV had established his residence at the Ennaton monasteries to the west of Alexandria for fear, according to the History of the Patriarchs, of his Chalcedonian rival. ${ }^{113}$ Like his predecessor Damian also resided at the Ennaton complex, ${ }^{114}$ and seems to have been in possession of a mere two churches at Alexandria: that of Cosmas and Damian, and that of the Angelion (hence the sometime soubriquet of his followers, the 'Angelitai'). ${ }^{115}$ His relationship with his Chalcedonian counterpart appears, from the little we can ascertain of it, to have been tense but not violent. John of Nikiu's Chronicle states that John IV renounced persecution; ${ }^{116}$ although in John of Ephesus the patriarch has certain of Damian's clerics arrested and deported to the capital - indicative, perhaps, not so much of intellectual disagreements per se than of the conflicts which resulted from the creation of an alternative patriarchal curia. ${ }^{117}$ The same ambiguous picture pertains to John's successor Eulogius. ${ }^{118}$ From the Bibliotheca of Photius we ascertain that Eulogius's synodical letter was received in Rome with consternation, for it had not been clear enough either in its acceptance of Chalcedon or in its condemnation of the council's detractors (suggesting, therefore, a deliberate attempt to avoid the

110 Although see on the Barsanuphites: History of the Patriarchs (Vulgate Recension) (ed. Evetts PO 1 474-475), with Maspero, Histoire des patriarches (cf. n. 6) 290-291.

111 For a Gaianite community at the Pempton in 601, see the inscription in Eajtar - Wipszycka, "L'epitaphe de Duhêla” (cf. n. 11); for Gaianite clerics in Alexandria in the 610s see n. 122 below. In the seventh century named leaders of the Gaianites appear in History of the Patriarchs (ed. Evetts PO 1 479, PO 5 34) and Sophronius, Synodical Letter 6.3.1. Anastasius of Sinai, Hodegos 23 ed. K.-H. Uthemann, Anastasii Sinaitae Viae dux, CCSG 8, Turnhout 1981, also still regarded them as significant (c.686/9-c.701). For the subsequent history see Kofsky, “Julianism” (cf. n. 10) 255.

112 See Jülicher, “Die Liste” (cf. n. 29) 19.

113 See History of the Patriarchs of Alexandria (Vulgate Recension) (ed. Evetts PO 1471-472).

114 Ibid. (Evetts PO 1473). Note also that ibid. (ed. Evetts PO 1481) makes Andronicus the first to reestablish residence in Alexandria (at the Angelion), rather than in its monasteries. Maspero, Histoire des patriarches (cf. n. 6) 283-284 (followed in Müller, "Damian, Papst” [cf. n. 102] 121) has Damian venturing into Alexandria on five occasions, but in the sources cited it is far from clear that 'Alexandria' is being used with such precision i.e. that it excludes the Ennaton.

115 See History of the Patriarchs (Vulgate Recension) (ed. Evetts PO 1 467, 479), both making the claim about the churches (so that one presumes continuity under Damian). Angelitai: Timothy of Constantinople, On Those Who Enter the Church (ed. PG 86 53, 60). For the location of the churches see Maspero, Histoire des patriarches (cf. n. 6) 141 nn. 2-3.

116 John of Nikiu, Chronicle 94 (ed. Zotenberg 168).

117 John of Ephesus, Ecclesiastical History 3.4.37- 38 (cf. ibid. 3.4.42 for their subsequent release). On John cf. Maspero, Histoire des patriarches (cf. n. 6) 256-258.

118 For Eulogius's theology, and the difficulties in assessing its tone based on the descriptions of Photius and the fragments in the Doctrina Patrum, see Grillmeier - Hainthaler, Christ in Christian Tradition (cf. n. 10) vol. 2 pt. 4, 65-71. 
issue). ${ }^{119}$ But from the same source we also ascertain that later in his career the patriarch composed a number of polemical texts against the anti-Chalcedonians, including one, Against the Theodosians and Gaianites, in which he denounced a recent (failed) union of the two sects, and proclaimed illegitimate the claim to oikonomia, or doctrinal accommodation, upon which it had been based. ${ }^{120}$ Our sources, therefore, suggest a complex and variable coexistence, and the relationship of the two patriarchs must in fact have been far more multifaceted than we can appreciate on the basis of our limited evidence - not least, because the creation of a new patriarchate and episcopate will have created an unprecedented competition for resources. How these tensions were resolved, if at all, we can but presume. ${ }^{121}$ Some mutual modus operandi must have evolved over time; but the precise complexities remain obscure. ${ }^{122}$

Damian's residence at the Ennaton complex, and his tense existence alongside a Chalcedonian rival, were recreated throughout his new episcopate. Above I have listed the remarkable number of Severan bishops whose names and sees are known to us in this period. But of all the patriarch's bishops, perhaps the most celebrated is Pesynthius of Koptos, with whom this article began. According to the earliest version of an extant encomium on Pesynthius, he was an ascetic in the western Theban region whom Damian consecrated as bishop of Koptos (before c.606), but who lived until 631, and thus witnessed both the Persian invasion and the Roman reoccupation. ${ }^{123}$ No other such encomium exists for Pesynthius's episcopal colleagues, but his modern fame is nevertheless connected to another set of sources: an extensive archive, in Coptic, of the bishop's correspondence. This archive was uncovered in

119 The papal response is recorded in Photius, Bibliotheca ed. I. Bekker, Photii Bibliotheca, Berlin 1824, cod. 230. For Eulogius's actions against heretics however cf. Gregory the Great, Letters 7.37, 8.29, 10.14, 12.16, 13.43. On Eulogius in general see Maspero, Histoire des patriarches (cf. n. 6) 259-275. 120 Photius, Bibliotheca (ed. Bekker cod. 227, 230); cf. CPG 6976. This union seems not to be identical with that of 565/6 (above p. 164). Eulogius (as per Photius) indicates that the union did not last, and a fragmentary festal letter contained in a single Coptic manuscript, which Alberto Camplani dates to 596 and ascribes to Damian, once again denounces aphthartist doctrine; see A. Camplani, "Coptic Fragments from a Festal Letter of the Late Sixth Century (John Rylands Library, Coptic Suppl. N. 47-48): Damian or Eulogius?" in M. Immerzeel et al. (eds.), Coptic Studies on the Threshold of a New Millennium: Proceedings of the Seventh International Congress of Coptic Studies, Leiden, August 27-September 2, 2000, Leuven 2004, 317-327.

121 These potential tensions are explored in E. Wipszycka, "The Institutional Church," in R. Bagnall (ed.), Egypt in the Byzantine World, Cambridge, 2007, 331-349, at 344-346; also ead. Alexandrian Church (cf. n. 42) 123-124; J. van der Vliet, "Pesynthios of Coptos/Qift (ca. 568-632) and the Rise of the Egyptian Miaphysite Church," Journal of the Canadian Society for Coptic Studies 3-4, 2012, $27-42$, at 30.

122 A hint of comparable complexities with respect to the Gaianites occurs in Sophronius, Miracles of Cyrus and John 12 (c.610 - c.614), where we discover one hundred Gaianite clerics using the Alexandrian church of Theonas after the Chalcedonian service.

123 For the encomium see above n. 1; for more detail on Pesynthius's life and previous discussion of his episcopal dates, see Booth, "A Circle of Egyptian Bishops" (cf. n. 7). 
two phases: first, the appearance on the antiquities market of various relevant documents during the nineteenth century; and, second, the discovery of more during archaeological explorations at the so-called 'Monastery of Epiphanius' (modern Šeikh 'Abd al-Qurna) in Western Thebes in 1911-1914. It appears that all of these documents derive from the same site. Although the archive still lacks a proper modern edition, a team of scholars divided between Leiden and the Louvre is at present finalising its publication. ${ }^{124}$

The archive affords us a precious glimpse of a bishop in action: intervening in rural disputes, interacting with secular officials, and enforcing ecclesiastical (and monastic) discipline. ${ }^{125}$ But what reason is there to associate the archive with Pesynthius of Koptos rather than, for example, the Pesynthius known to have served as bishop of Hermonthis in the same period? The 'Monastery of Epiphanius' was located, after all, within the jurisdiction of Hermonthis, ${ }^{126}$ and at least one more of its contemporaneous bishops - Abraham, on whom more below - is known to have resided in a monastery within walking distance; in one document, moreover, the author asks Psan, the disciple of Epiphanius, to solicit 'the bishop Apa Pesynthius' to intervene in the affairs of Hermonthis. ${ }^{127}$ Several features of the archive nevertheless suggest that the bishop Pesynthius concerned (assuming it is a single person) might be the celebrated incumbent of Koptos: two papyri make explicit reference to 'Apa Pesynthius bishop of Koptos'; ${ }^{128}$ another is sent to 'bishop Pesynthius' from Koptos itself; ${ }^{129}$ and numerous documents recovered from, or associated with, the site refer to the towns or villages which surrounded that same see. ${ }^{130}$ It therefore seems, as Crum long ago proposed, that our bishop Pesynthius is Pesynthius of Koptos, and that he was performing his episcopal duties, and receiving his correspondence, at a rural monastic retreat within a different jurisdiction. ${ }^{131}$

Whilst here, moreover, Pesynthius was also dealing with appeals addressed from neighbouring dioceses. The request from Hermonthis has been noted above; one os-

124 For more detail see e.g. van der Vliet, "Pisenthios de Coptos" (cf. n. 4); R. Dekker, "Reconstructing and Re-Editing the Archive of Bishop Pesynthios of Koptos/Keft (7 $7^{\text {th }}$ century)," in M. Horn et al. (eds.), Proceedings of the Eleventh Annual Symposium Which Took Place at Leiden University, Oxford 2011, 33-41. See also Booth, “A Circle of Egyptian Bishops” (cf. n. 7).

125 On this see M. C. Giorda, "Bishops-Monks in the Monasteries: Presence and Role,” Journal of Juristic Papyrology 39, 2009, 49-82, at 59-65; van der Vliet, "Rise of the Egyptian Miaphysite Church" (cf. n. 121).

126 H. E. Winlock - W. E. Crum, Monastery of Epiphanius, 2 vols, New York 1926, vol. 1, 105.

127 See P.Mon.Epiph. 172.

128 See P.Pisentius 11 (апа пєсүмөюс пєпєк/ $\overline{\mathrm{N}} \overline{\mathrm{B}} \mathrm{T}$ ); and, from the Philips collection, O.CrumST 174 (дпа пєсүменос [пепскопос к] кчт).

129 P.Mon.Epiph.152.

130 As pointed to in Winlock - Crum in Monastery of Epiphanius (cf. n. 126) vol. 1224 . For the same villages see also F. Calament, "Le programme d'édition des archives de Pesynthios: focus sur les papyrus coptes du Musée du Louvre," in P. Schubert (ed.), Actes du $26^{e}$ Congrès international de papyrologie (Genève 2010), Geneva 2012, 107-118, at 114.

131 Winlock - Crum, Monastery of Epiphanius (cf. n. 126) vol. 1224. 
tracon perhaps addressed to the bishop seems to concern the clerics of Jeme; ${ }^{132}$ but most remarkable is Pesynthius's repeated interaction with the clerics and officials of Qus, ${ }^{133}$ a town to the south of Koptos. ${ }^{134}$ That interaction is remarkable because Qus appears to have had its own contemporaneous bishop also allied to the Severan patriarchate. Thus in P.Pisentius 11 one Pisrael bishop of Qus - no doubt identical with that Pisrael who appears elsewhere in the archive as a bearer of letters from the patriarch to two other bishops, to whom we shall return ${ }^{135}$ - features alongside Pesynthius, as well as bishop Antonius of Ape (to the north of Hermonthis) ${ }^{136}$ and Psan the disciple of Epiphanius ${ }^{137}$ on a council of local religious notables. ${ }^{138}$ The bishops and Psan are there said to have assembled to examine the case of an errant archimandrite at Psenhōr, a village which elsewhere appears to be in the district of Qus. ${ }^{139}$ But here it is Pesynthius, and not Pisrael, whom the archimandrite attempts to placate, as though Pisrael (and Antonius) were somehow Pesynthius's subordinate. How do we explain this? The answer is far from clear. Perhaps this was the usual order of episcopal enquiries, which are otherwise absent from our evidence; or perhaps we might imagine that Pesynthius's reputation gave him some special status in the region, which other bishops were de facto forced, or disposed, to accept. But we

132 O.Crum 286, with W. E. Crum, "A Greek Diptych of the Seventh Century," Proceedings of the Society of Biblical Archaeology 30, 1908, 255-65, at 262, calling Pesynthius's role 'somewhat that of a metropolitan among his neighbouring colleagues.'

133 See P.Pisentius 5, 18 (an appeal for intervention at Qus), 18bis (a response to the priest Paul and the clerics of Qus), 19 (providing information on the problems in the 'eparchate of Kos'). The villages Pisenai and Psenhōr in the archive were also within the district of Qus; see above n. 130. Cf. also Dekker, "Reconstructing and Re-Editing" (cf. n. 124) 39.

134 For the location see Timm, Das christlich-koptische Ägypten (cf. n. 40) 2173-2180.

135 P.Pisentius 10 (as below p. 184). Pisrael is the author, it seems, of P.Pisentius 7 and the recipient of P.Pisentius 8; he is also perhaps the 'bishop Pisrael' who appears in O.CrumST 255 and P.Mon.Epiph 150,426 . It is not certain that this person is identical with the Pisrael who sometimes appears alongside one (bishop?) Ananias in certain ostraca e.g. O.Brit.Mus.Copt. 27-28 no. 21233 (as suggested in Winlock - Crum, Monastery of Epiphanius [cf n. 126] vol. 1133-135; and again in H. Behlmer, "Christian Use of Pharaonic Sacred Space in Western Thebes: The Case of TT 85 and 87," in P. Dorman - B. Bryan [eds.], Sacred Space and Sacred Function in Ancient Thebes, Chicago 2007, 163-75, at 167-168, with further ostraca from TT 85 where the pair appear together). If this Ananias were indeed the bishop of Hermonthis who appears on the Bryce-Moir Diptych (as Crum and Behlmer suggest), then the Pisrael with whom he associated was in all likelihood an earlier figure, since the bishops on the diptych are listed in chronological order, and Ananias is the tenth bishop, where Abraham of Hermonthis, who was active $c .600$ (below p. 178), is the fourteenth.

136 Ape is sometimes identified as Luxor/Thebes but see Timm, Das christlich-koptische Ägypten (cf. n. 40) 133-136. Antonius is perhaps identical with the 'bishop Antonius' who appears in O.Crum 344. 137 For Psan who sends and receives numerous letters in the documents from the Monastery of Epiphanius, see Winlock - Crum, Monastery of Epiphanius (cf. n. 126) vol. 1222-223. On his presence see van der Vliet, "Rise of the Egyptian Miaphysite Church" (cf. n. 121) 33.

138 For this case see also E. Revillout, "Une affaire de moeurs au $7^{\mathrm{e}}$ siècle," Zeitschrift für ägyptische Sprache und Altertumskunde 17, 1879, 36-39.

139 See above n. 133. 
might also be tempted somehow to associate Pesynthius's capacious influence with the new forms of hierarchical organisation which, as we shall see, were also emerging elsewhere within the episcopate.

How long did Pesynthius reside in the community? The number of documents does not provide much help, since we must presume that much has been lost. But the site itself is small, and it is difficult to suppose that it could have contained a bishop and his retinue - of whom there is, in any case, little indication in the material - for a long period. ${ }^{140}$ Nor is it clear, moreover, that we must imagine a single, extended period of residence rather than, for example, a seasonal period of retreat, or a regular visitation, across several years. ${ }^{141}$ Can we at least isolate the period in which the bishop was there? The documents associated with Pesynthius provide no chronological markers. But in light of the Encomium, it has proved tempting to associate his presence at the monastery with the period of the Persian occupation, during which Pesynthius is said to have withdrawn to 'the mountain of Jeme' that is, the region in which the 'Monastery of Epiphanius' was situated. ${ }^{142}$ This would place our documents in the period c.619-c.629.

There are nevertheless some problems with this context. The Encomium suggests that Pesynthius's withdrawal to the 'mountain of Jeme' was driven through fear of the Persians, and perhaps he did indeed retreat there for a period of time - a number of documents bear witness to contemporaries' distress at their advance. ${ }^{143}$ There is little indication, however, that the subsequent Persian occupation witnessed a persecution of bishops, even if the conquerors are said, within the synaxarium, to have prevented new episcopal appointments. ${ }^{144}$ Moreover, as Ewa Wipszycka has pointed out, if this period of alleged occultation corresponds to the period of residence witnessed in the archive, then Pesynthius's frequent correspondence with neighbouring regions did little to disguise his presence from his persecutors. ${ }^{145}$ It is quite possible therefore that the archive belongs to an earlier period, and perhaps to a quite different context. At the least, as we shall now see, we do not need the context of the Persian occupation to explain the bishop's residence within a rural monastery. For within the lifetime of Damian, and thus well before the Persian invasion, at least one other bishop had made the same choice.

140 Cf. Wipszycka, Alexandrian Church (cf. n. 42) 41.

141 Note that in P.Mon.Epiph. 126, 224, 382 the author, a Pesynthius, refers to having come 'south', which (assuming the author is a single person) might all refer to a single event, or a regular visitation of the area.

142 On the meaning of 'mountain of Jeme' see the discussion of Crum in Winlock - Crum, Monastery of Epiphanius (cf. n. 126) vol. 1 107-108.

143 See e.g. R. Altheim-Stiehl, “The Sasanians in Egypt - Some Evidence of Historical Interest,” Bulletin de la Société d'archéologie copte 31, 1992, 87-96.

144 See below n. 172.

145 Wipszycka, Alexandrian Church (cf. n. 42) 41. 
At a short walk from Pesynthius's residence at the 'Monastery of Epiphanius' was the Monastery of Phoibammon (at modern Deir al-Bahari), where presided the bishop Abraham of Hermonthis. The principal means through which Abraham is known is another Coptic archive, extant on over two hundred ostraca and limestone chips. This archive is also unedited, although one hundred and fourteen of the relevant documents were collected together in the 1952 doctoral thesis of Martin Krause, ${ }^{146}$ who has since contributed a number of important further studies. ${ }^{147}$ One document (O.Crum Ad. 59) suggests that the patriarch Damian had once requested that Abraham relocate his monastery, and thus also his episcopal residence, to a more convenient location - a further striking example, we should note, of the patriarch's interference in the affairs of his episcopate - and that the site at Deir al-Bahari was therefore a new foundation established in accordance with Damian's demand (as suggested also in P.KRU 105). ${ }^{148}$ This same site is the source of Abraham's archive.

In that archive we discover Abraham ordaining clerics, making liturgical arrangements, and presiding over church discipline. ${ }^{149}$ Like his colleague Pesynthius, however, Abraham performs his duties from a monastery, in which he is, furthermore, archimandrite (and proprietor). Thus although we cannot determine the nature or duration of Pesynthius's presence at the 'Monastery of Epiphanius', it is more probable if not certain that Abraham, at least, was a permanent resident within his own community. Was this a widespread phenomenon? Within the synaxarium there is perhaps a suggestion that another of Damian's bishops, Constantine of Assiut, resided as bishop within his former monastery, ${ }^{150}$ and at least some of the encomia associated with the circle were performed at rural shrines (with perhaps attendant monasteries), as though this were their powerbase. ${ }^{151}$ Several documents from

146 M. Krause, Apa Abraham von Hermonthis: ein oberägyptischer Bischof um 600, unpublished Berlin thesis, 2 vols, 1952.

147 See esp. M. Krause, “Die Testamente der Äbte des Phoibammon-Klosters in Theben,” Mitteilungen des Deutschen Archäologischen Instituts, Abteilung Kairo 25, 1969, 57-69; id., "Die Beziehungen zwischen den beiden Phoibammon-Klöstern auf dem thebanischen Westufer," Bulletin de la Société d'archéologie copte 27, 1985, 31-44.

148 Krause, "Die Beziehungen” (cf. n. 147).

149 For this see esp. G. Schmelz, Kirchliche Amtsträger im spätantiken Ägypten nach den Aussagen der griechischen und koptischen Papyri und Ostraka, Munich 2002, for which Abraham's archive is a central source. See also, building from Schmelz, Wipszycka, Alexandrian Church (cf. n. 42) 305-335. 150 The entry from the Upper Egyptian synaxarium published in R.-G. Coquin, "Saint Constantin, évêque d'Asyūt,", Studia Orientalia Christiana: Collectanea 16, 1981, 151-170, at 154-155, states that '... they buried him in his monastery in which he was living امام his episcopal palace (اسقفيته).' The Arabic preposition should mean 'opposite', but Coquin has suggested that it might represent an original Greek/Coptic ảvtì, which could be 'opposite' but also 'instead of', which Coquin prefers (168; in part however upon on the basis of wider evidence for the rustication of the episcopate).

151 See A. Papaconstantinou, "The Cult of Saints: A Haven of Continuity in a Changing World?" in R. Bagnall (ed.), Egypt in the Byzantine World, Cambridge 2007, 350-67, at 359-360, suggesting that Constantine of Assiut's celebration of St Claudius at the village of Pohe, near Assiut, might indicate that 'his episcopal authority [was] restricted to a rural network.' To this we might add the village of 
Western Thebes also suggest that Pesynthius and Abraham were not alone amongst contemporaneous bishops in visiting or residing in the region. Thus a small number of extant texts were written to or from, for example, the bishops John, Andrew, and (in particular) Ananias. ${ }^{152}$ All of their sees, and precise dates, are at present unknown.

How should we interpret their presence? First of all it should be said that the phenomenon of bishops living in monasteries is not unknown in earlier Egypt; ${ }^{153}$ but it nevertheless does not seem coincidental that these two episcopal archives, which are otherwise unique, both derive from this same period - this suggests a changed context. (Assuming that earlier bishops also kept archives, we must imagine that these were produced, stored, and lost in cities). The obvious temptation is to associate the rural situation of our bishops with the sudden creation of a mass of antiChalcedonian hierarchs. An obvious source for such recruits - within a context in which few 'orthodox' bishops remained - was the monasteries, and indeed such biographical details as we possess for Damian's bishops emphasise their monastic origins. ${ }^{154}$ It is possible, therefore, that these new bishops, thrust into episcopal office, were more committed than their earlier counterparts to monastic regimens, and that this commitment explains their permanent or intermittent residence in monasteries.

Wipszycka has, however, suggested a different explanation. She points out that the archives of Pesynthius and Abraham are remarkable for the absence of evidence for their bishops' interaction with their actual cities, Koptos and Hermonthis - their extant correspondence is instead concentrated around the villages and towns which surrounded them. Perhaps, in the case of Pesynthius, we might dismiss this as an illusion of the evidence, which witnesses a particular aspect of the bishop's activities,

Hameioor, near Assiut, where Constantine performed the First Encomium for John of Heraklea; see G. Garitte, “Constantin, évêque d'Assiut," in Coptic Studies in Honour of Walter Ewing Crum, Boston 1950, 287-304, at 296. Papaconstantinou also notes that John of Hermopolis, Encomium on Anthony 38 ed. G. Garitte, "Panégyrique de saint Antoine par Jean, évêque d'Hermopolis," Orientalia Christiana Periodica 9, 1943, 100-134, 330 -365, at 346 places its performance 'before a shrine far from the city' (although he was not, according to the title, bishop at the time) but also suggests that Pesynthius of Koptos perhaps performed his Encomium on Onophrius in the village of Pallas, near to Koptos (so also W. E. Crum, "Discours de Pisenthius sur Saint Onnophrius,” Revue de l'Orient chrétien 20, 19151917, 38-67, at 40-41).

152 John: P.Mon.Epiph. 133; Andrew: O.CrumST 326; O.Crum 288; with Winlock - Crum, Monastery of Epiphanius (cf. n. 126) 133-135. Ananias: P.Mon.Epiph. 565, with Behlmer, "Christian Use of Pharaonic Sacred Space” (cf. n. 135) for further texts from TT 85 associated with an 'Ananias', perhaps the bishop of P.Mon.Epiph. 565. On the question of his identification with Ananias, bishop of Hermonthis, see above n. 135.

153 See e.g. E. Drioton, "La discussion d'un moine anthropomorphite audien avec le patriarche Théophile d'Alexandrie en l'année 399," Revue de l'Orient chrétien 10, 1915-1917, 92-100, 113-128, in which the protagonist, bishop Aphou of Pemje/Oxyrhynchus, lives within a monastery but goes to his city once a year. The date of the text is, however, uncertain.

154 For more detail see Booth, "A Circle of Egyptian Bishops” (cf. n. 7); see also Giorda, "BishopsMonks” (cf. n. 125) 54-82. 
and is not representative of the whole - but in the case of Abraham, whose permanent residence at Deir al-Bahari seems more assured, this dismissal is more difficult. Wipszycka instead suggests that the particular situations of Pesynthius and of Abraham are to be explained in a special circumstance, through which incumbent Chalcedonian bishops controlled the cities, and their new, anti-Chalcedonian rivals operated, from monasteries, in the same cities' hinterlands. ${ }^{155}$ This is without doubt the situation in Alexandria, where both Peter IV and Damian resided in a monastic complex nine miles from the city. ${ }^{156}$ But as we have seen, Chalcedonian bishops also existed elsewhere, and Peter's appointment of rival bishops cannot but have recreated the same tensions outside of Alexandria. The suggested situation, moreover, also finds a parallel elsewhere in the Near East where, as we have seen above, the creation of the Jacobite episcopate, in a context of imperial opposition, also entailed the effective rustication of its members within monasteries. ${ }^{157}$ It remains striking that these supposed rivalries have left no traces in our sources, whether in the aforementioned archives or in the various extant texts attributed to our bishops. ${ }^{158}$ This silence over Chalcedon need not, however, tell against Wipszycka's thesis, if it is intended to efface the existence of competitors, or if the bishops feared offending a more powerful rival. But that thesis remains, for now, an argument from silence.

\section{The Creation of the Vicarate}

If the presence of Chalcedonian bishops in cities perhaps explains the monastic residence of the bishops of Koptos and Hermonthis, then it perhaps also explains another evident innovation: the creation of the patriarchal vicar. We have observed above that the Second Encomium on Saint Colluthus ascribed to one 'Phoibammon of Panopolis' is inauthentic; but it is also therefore a dubious witness to the existence, in the period of Theodosius's exile, of the office which Phoibammon is said to have held: the vicarate. ${ }^{159}$ The first reliable evidence for its creation belongs, in fact, to the patriarchate of Damian, and its first known occupant is the aforementioned Constantine, bishop of Assiut. ${ }^{160}$ In the Upper-Egyptian recension of the Coptic synaxarium - and not in the Lower-Egyptian equivalent - Constantine is celebrat-

155 See Wipszycka, "Institutional Church" (cf. n. 121) 345; repeated in ead., "Les élections épiscopales” (cf. n. 57) 267-269; Alexandrian Church (cf. n. 42) 141-142.

156 See above nn. 113-114.

157 See above n. 19.

158 For further discussion see Booth, “A Circle of Egyptian Bishops” (cf. n. 7).

159 Pace e.g. Wipszycka, Alexandrian Church (cf. n. 42) 143.

160 See Timm, Das christlich-koptische Ägypten (cf. n. 40) 235-251 (239-240 on Constantine, and speculating that he might have been bishop when John Moschus visited; see Pratum Spirituale 161). 
ed on the $9^{\text {th }}$ of Amšĩr. ${ }^{161}$ Besides the usual platitudes concerning his manifold virtues, the entry on Constantine makes several significant claims concerning his career: that he received the monastic habit from the hand of his brother Moses, along with ten others; that among the ten were also Rufus bishop of Shotep ${ }^{162}$ and Joseph bishop of Apollinopolis Parva ${ }^{163}$; and that his elevation to the episcopate occurred under the patriarch Damian, who also made him his 'vicar for Upper Egypt' (نائب على الوجه القبلى). The text then claims that, upon his death, he was buried 'in his monastery, in which he was staying opposite [or instead of] his episcopal see known as al-Hanāda, on the mountain of Assiut.. ${ }^{166}$ The synaxarium therefore places the beginning of Constantine's episcopal career during the patriarchate of Damian, and thus 577-c.606.

The Upper-Egyptian synaxarium contains a further notice pertinent to Constantine's career. ${ }^{167}$ Under the $20^{\text {th }}$ Kiyahk the text commemorates Pesynthius of Hermonthis. ${ }^{168}$ This reports that Pesynthius - who was elected to be bishop of Hermonthis while a monk 'in a monastery east of Qașr Tawd'169 - was sent, before his ordination in Alexandria, to Antinoe, ${ }^{170}$ and there met with 'Senuthes vicar of the patriarch for Upper Egypt (نائب البطريرك على الوجه القبلى ') and Constantine bishop of Assiut, so that the

161 The entry on Constantine was published incomplete from BN ar. 4895f. 51 ${ }^{\mathrm{rv}}$ in Garitte, "Constantin" (cf. n. 151) 300-301; but then published in full from a manuscript from Luxor in Coquin, "Saint Constantin" (cf. n. 150) 154-155 (on the ms. see id. "Le synaxaire des Coptes: un nouveau témoin de la recension de Haute-Egypte," Analecta Bollandiana 96, 1978, 351-365). On the competing modern editions of the Copto-Arabic Synaxarium - in particular R. Basset, Le synaxaire arabe jacobite (rédaction copte), Patrologia Orientalis 1, 3, 11, 16, 17, Paris 1904-1923, and J. Forget, Synaxarium Alexandrinum, CSCO 47, 48, 49, 67, 78, 90, Beirut and Louvain 1905-1926, which interweave the southern and northern recensions - see R.-G. Coquin, "Le synaxaire des Coptes: un nouveau témoin de la recension de Haute-Egypte," Analecta Bollandiana 96, 1978, 351-365; id., "Editions of the Synaxarion,” in Atiya, Coptic Encyclopaedia (cf. n. 40) 2171-2173; M. Swanson, "The Copto-Arabic Synaxarion," in D. Thomas - A. Mallett (eds.), Christian-Muslim Relations: A Bibliographical History Volume 5 (1350-1500), Leiden 2013, 93-100.

162 See Timm, Das christlich-koptische Ägypten (cf. n. 40) 2416-2424.

163 Ibid. 1433-1438. Joseph seems to be otherwise unknown (ibid. 1434).

164 For the phrase الوجه القبلى to designate 'Upper Egypt' Coquin, “Saint Constantin” (cf. n. 150) 158 n. 1 points to J. Maspero - G. Wiet, Matériaux pour servir à la géographie de l'Égypte, Cairo 1919, 227-230.

165 On this phrase see above n. 150.

166 Coquin, "Saint Constantin” (cf. n. 150) 154-155; on 'al-Hanāda' cf. W. E. Crum, Theological Texts from the Coptic Papyri, Oxford 1913, 186 with nn. 5-6.

167 See Copto-Arabic Synaxarium (ed. Basset PO 3 490; Forget I 345-346) (both from the fragmentary ms. of the Upper-Egyptian recension in $\mathrm{BN}$ ar. 4869). The missing preceding text was published in Winlock - Crum, Monastery of Epiphanius (cf. n. 126) vol. 1136 n. 2 from a manuscript at Luxor (apparently distinct from that described in n. 161 above; see Coquin, "Le synaxaire" [cf. n. 161] 358). For analysis and partial translation see also Garitte, "Constantin” (cf. n. 151) 303, with the corrections of Coquin, "Saint Constantin" (cf. n. 150) 160.

168 See Timm, Das christlich-koptische Ägypten (cf. n. 40) 152-182.

169 Ibid. 2862.

170 Ibid. 111-128. 
pair could confirm his election before the patriarch ordained him. The clear suggestion of the text is that Senuthes was bishop of Antinoe. When Pesynthius's episcopal ordination occurs (under an unnamed patriarch), it does so in the presence of the bishops Abraham (or Ephrem) of Diospolis Parva ${ }^{171}$ and Pesynthius of Koptos. ${ }^{172}$ The latter's episcopate, as we have seen, commenced in the patriarchate of Damian (577-c.606), perhaps in 598/9; but it ended in 631. ${ }^{173}$ René-Georges Coquin's understanding of our two notices was therefore that Constantine was made vicar of Upper Egypt in the late patriarchate of Damian, perhaps replacing in that role the aforementioned vicar Senuthes, who thus would have died before $c .606 .{ }^{174}$

A recent paper of Amin Benaissa has nevertheless challenged this understanding, and instead argued that Senuthes was Constantine's successor in the vicarate. ${ }^{175}$ Benaissa identified the 'Senuthes' of the synaxarium with the 'abba Senuthes the [most holy] bishop' who appears in CPR XXII 2, a document from the Hermopolite in which the bishop represents the nosokomeion Basileiou, a famous institution of Antinoe. The text is dated to a second indiction, and on the basis of the appearance therein of the pagarch Athanasius, Benaissa suggested that it might date to 628/9 - it has since become more probable, however, that it belongs to 643/4. ${ }^{176}$ Although the identification of this Senuthes, bishop of Antinoe, with ours is therefore far from certain, it nevertheless remains possible that the earlier Senuthes was indeed Constantine's successor, replacing him while he was still alive. Benaissa points out that the ordination of Pesynthius of Hermonthis - which, in the account of the synaxarium, happens while Senuthes is vicar and Constantine bishop - might well have occurred after Damian's patriarchate, and suggests moreover that the apparent demotion of Constantine, whom we might otherwise have expected to have held the vicarate for life, might be explained through various reasons, in particular a change of patriarch.

171 Ibid. 1120 - 1125.

172 See Copto-Arabic Synaxarium (ed. Basset PO 3 490; Forget I 346). Note that the same notice continues to describe how, during the Persian occupation, ordinations of new bishops were banned, so that upon the death of the bishop of Isnā (= Latopolis) 'the patriarch' wrote to Pesynthius 'to appoint him to the vicarate over the city’ (بالنيابة على مدينة), a post which he executed for seven years alongside his other episcopal duties.

173 See Booth, "A Circle of Egyptian Bishops" (cf. n. 7) for discussion of the dates.

174 Coquin, "Saint Constantin" (cf. n. 150) 160-161.

175 A. Benaissa, “Two Bishops Named Senuthes: Prosopography and New Texts," Zeitschrift für Papyrologie und Epigraphik 166, 2008, 179-194. Note that, like Benaissa, I refer to 'Senuthes' throughout the following analysis, although his name in Greek varies between 'Senouthios' and 'Senouthes', and in Coptic is 'Shenoute'.

176 Benaissa followed F. Morelli, Documenti greci per la fiscalità e la amministrazione dell'Egitto arabo, Corpus Papyrorum Raineri XXII, Vienna 2001, 28; but the subsequent publication of more texts associated with Athanasius suggests that 643/4 is the more probable date; see id., L'archivio di Senouthios Anystes e testi connessi, Corpus Papyrorum Raineri XXX, Vienna 2010, 22 n. 34. 
We can in fact be quite confident that Pesynthius of Hermonthis was consecrated after the patriarchate of Damian. ${ }^{177}$ For it is confirmed in a contemporaneous object, the so-called 'Moir Bryce Diptych' now held in the British Museum. ${ }^{178}$ This remarkable ivory diptych, the (illegible) original text of which has been overwritten with the current visible text, catalogues the persons to be commemorated during the eucharistic celebration. It begins with a list of the living - the contemporaneous patriarch, the local bishop, the clergy and the people -, invokes a series of saints (the Virgin, Baptist, Evangelists, and Apostles), and then provides two lists: one for the deceased Severan patriarchs of Alexandria, which culminates in Andronicus, who died c.625; ${ }^{179}$ and another which has been identified as the deceased bishops of Hermonthis, ${ }^{180}$ and which culminates in Abraham and Moses, of whom the former is no doubt the famous bishop appointed under Damian (to whom we shall return). ${ }^{181}$ We can thus surmise that these lists were produced under Andronicus's successor Benjamin, who died c.665. ${ }^{182}$ Indeed, after Benjamin's death it is evident that both the name of the contemporaneous patriarch and the patriarchal list have been updated, for a third hand has altered the present patriarch's name to 'Agathon', and then added 'Benjamin' to the list of the deceased. For our purposes, however, the most striking feature of the diptych is the given name of the contemporaneous bishop: Pesynthius, who does not otherwise appear on the list of Hermonthis' bishops. (This, we should note, must be the Pesynthius of Hermonthis recorded in the synaxarium, and cannot be Pesynthius of Koptos. $)^{183}$ When the patriarchal list was updated under Agathon, Pesynthius's name, and the episcopal list, was unaltered - this, we must assume, reflects an oversight, rather than the survival of the bishop up to the mid-660s. But the earlier text of the diptych at least demonstrates that Pesynthius of Hermonthis was still active in the 620s, under Andronicus; and that between Pesynthius's episcopate

177 See G. Gabra, "Pesynthius, Bischof von Hermonthis," Mitteilungen des Deutschen Archäologischen Instituts Abteilung Kairo 40, 1984, 27-29.

178 See Crum, “A Greek Diptych” (cf. n. 132).

179 See Jülicher, “Die Liste” (cf. n. 29) 14-15. Andronicus's dates are relative to those of Anastasius. 180 Cf. the (perhaps excessive) caution of Timm, Das christlich-koptische Ägypten (cf. n. 40) 159. 181 Note that the diptych names the predecessor of Abraham as Andrew, perhaps the bishop Andrew who sends O.Crum 288, and receives O.CrumST 326 (see also Winlock - Crum, Monastery of Epiphanius [cf. n. 126] vol. 1 135).

182 Jülicher, "Die Liste” (cf. n. 29) 11-13.

183 As first suggested in Crum, “A Greek Diptych” (cf. n. 132) 259-62. He withdrew the identification after criticism in id., "The Bishops named in Mr Bryce's Diptych," Proceedings of the Society of Biblical Archaeology 31, 1909, 288, and then made the link with Pesynthius of Hermonthis in Winlock - Crum, Monastery of Epiphanius (cf. n. 126) vol. 1, 136. It is possible that Pesynthius of Hermonthis is also the 'thrice-blessed' (and therefore deceased) bishop Pesynthius mentioned in a pastoral letter produced under Benjamin; see A. Camplani, "A Pastoral Epistle of the Seventh Century concerning the Eucharist (Pap. Berlin P. 11346),” in V. M. Lepper, Forschung in der Papyrussammlung: Eine Festgabe für das Neue Museum, Berlin 2012, 377-386. The letter also features a bishop Peter, whose see is unknown, but who seems also to be described as a hêgoumenos. On monk-bishops in this period see above pp. $174-180$. 
and that of Abraham (active under Damian) there had also intervened the episcopate of Moses. All this supports, therefore, Benaissa's contention that Pesynthius's consecration belongs to a later context. ${ }^{184}$

Benaissa's position is also complemented in a contemporaneous Coptic document which he cites but perhaps under-interprets. In this document, which Eugène Revillout published as part of the archive of Pesynthius of Koptos (P.Pisentius 10 recto), ${ }^{185}$ one Senuthes describes to the recipient, who is a monk Elisaius, ${ }^{186}$ how one 'Apa Pisrael, bishop' - who appears elsewhere in the archive as the bishop of Qus $^{187}$ - came bearing letters from the patriarch (патрідрхнс), destined for him and for 'Apa Constantine, bishop'. The context is a council which will soon gather in connection with the recipient. Senuthes then states:

'I sent them [the letters] southwards to my lord Apa Constantine the bishop in order that he read them, and the judgement (птю()) he will give ${ }^{188}$ to me will be executed. The archbishop has said to me that - it pains me to say it - you are to remain with me until he writes the judgement ...'

It will come as little surprise to discover that various scholars have made the connection with the Upper-Egyptian synaxarium, and linked the letter to the careers of Senuthes of Antinoe and (to the south) Constantine of Assiut. ${ }^{189}$ Can we be more precise about the context? Benaissa assumes that it dates to after Constantine's posited 'retirement', when he nevertheless still performed 'a vicar-like role alongside Senuthes' ${ }^{190}$ But the most obvious reading of the text is that Senuthes does not here consult, but rather defers to, Constantine, passing to him the eventual 'judgement' in the case - later in the letter, he indeed offers to forward further information to Constantine on behalf of the accused. ${ }^{191}$ It seems probable, therefore, that the docu-

184 Note that a 'bishop Pesynthius' appears also on an ostracon in which a woman of Jeme addressed a petition, extant on a sandstone ostracon, concerning the Persians' murder of her son and theft of her livestock (thus 619-629); see J. Drescher, “A Widow's Petition,” Bulletin de la Société d'archéologie copte 10, 1944, 91-96 (= SB Kopt. I 295). But van der Vliet, "Rise of the Egyptian Miaphysite Church" (cf. n. 121) 32 associates the document with Pesynthius of Koptos.

185 Revillout, "Textes coptes" (cf. n. 2), 1900, 145 no. 10.

186 The name falls in a lacuna in Revillout's edition of P.Pisentius 10 recto but is given in Winlock Crum, Monastery of Epiphanius (cf. n. 126) 229 n. 15 (апа є $\lambda_{1}$ [cגıc]). Ibid. 229-230 for the wider evidence related to him.

187 See above p. 176.

188 Revillout, “Textes coptes” (cf. n. 2), 1900, 145 reconstructs птю(a) qмaхоo)ч.

189 See e.g. Winlock - Crum, Monastery of Epiphanius (cf. n. 126) vol. 1137 n. 1; Garitte, "Constantin" (cf. n. 151) 303-304; Coquin, "Saint Constantin" (cf. n. 150) 161 n. 2.

190 Benaissa, "Two Bishops” (cf. n. 175) 182.

191 P.Pisentius 10 recto (Revillout 145): '(If you want to ask a question) I will write to Apa Constantine [and], see, (I will) give him the letter of your fraternity.' Note that in P.Mon.Epiph. 131 a Constantine who calls himself 'the most humble' (a form of episcopal self-reference) transmits to [the archimandrite] Epiphanius a letter of a patriarch through the deacon who brought to him the patriarch's festal letter (кнрүгмд). Garitte, “Constantin” (cf. n. 151) 304 suggests the text might be an autograph of 
ment dates in fact to the period of Constantine's vicarate under Damian, when Senuthes was a close collaborator but nevertheless of a lesser status. ${ }^{192}$

One final confirmation of Constantine's retirement comes in a text attributed to him, the Second Encomium on Saint Claudius. ${ }^{193}$ I have discussed Constantine's corpus, and the attribution of this text to him, elsewhere. ${ }^{194}$ But amongst those present at the encomium's performance, the text describes 'the representative of the archbishop (†атохос мпархєпіскопос),' who had come south. The archbishop is named as 'Apa Andronicus' (архєєпскопос апа амөромикос), the Severan patriarch

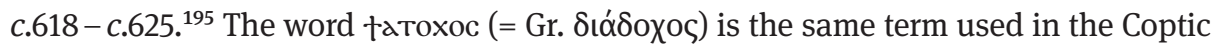
Encomium on Saint Colluthus to mean 'vicar' (= Ar. نائب), and this text, therefore, also indicates Constantine's later retirement or demotion from the office, and the presence of a successor in a place somewhere to the north (perhaps Senuthes in Antinoe). ${ }^{196}$

Once we have accepted the arguments of Benaissa, and discounted the evidence of the Encomium on Saint Colluthus attributed to 'Phoibammon of Panopolis', Constantine becomes the first known occupant of the vicarate, an office which thus seems to have arisen alongside the new episcopate, and which was otherwise alien to ecclesiastical norms within Egypt. The Alexandrian patriarch, in contrast to his counterparts elsewhere, did not have metropolitans, that is, regional bishops to whom the power of appointing lesser bishops, and gathering local councils, was devolved. But under Damian we witness within the new Severan church a more federal structure, in which the patriarch seems to cede certain powers over discipline and election: thus we find Damian instructing Constantine of Assiut to pass judgement in the case of an errant monk; ${ }^{197}$ and a successor of Damian refusing a candidate for the episcopate because he has not sought the approval, in advance, of Constantine and the patriarchal vicar Senuthes of Antinoe (who then approve, instead, Pesynthius of Hermonthis). ${ }^{198}$

Constantine. In P.Mon.Epiph. 133 Epiphanius is similarly apprised of a patriarchal order through the bishops John and Pesynthius.

192 Note that the names 'Constantine' and 'Senuthes' appear together also in P.Grenf. I 66 and in O.CrumVC 38 (see Garitte, "Constantin” [cf. n. 151] 304). It is possible that these persons are Constantine of Assiut and Senuthes of Antinoe; see the discussion in Benaissa, "Two Bishops” (cf. n. 175) $183-184$.

193 Cf. also Benaissa, “Two Bishops” (cf. n. 175) 183.

194 Booth, “A Circle of Egyptian Bishops” (cf. n. 7).

195 Constantine of Assiut, Second Encomium on St Claudius ed. G. Godron, Textes relatifs à Saint Claude d'Antioche, Patrologia Orientalis 35, Turnhout 1970, 508-669, at 592. For Andronicus see above n. 179.

196 Cf. above p. 156.

197 See above p. 184.

198 See Copto-Arabic Synaxarium (ed. Basset PO 3 490; Forget I 345), with reference to the subsequent appointment of Pesynthius of Hermonthis. 
The lack of contemporaneous documents from the Delta does not allow us to perceive developments there, but it is possible that here too Peter or Damian appointed a vicar - in the synaxarium Constantine is designated 'vicar for Upper Egypt', as if there might also be one for 'Lower Egypt', and in the late seventh century, at least, the Severan patriarch has a vicar-like figure (here called дпотрітнс) ${ }^{199}$ in both Nikiu (in the Delta) and in Kynopolis (in Middle Egypt). ${ }^{200}$ It is possible, then, that there were in this period two vicars; but it is also clear that the office did not attach to a particular see, but to a particular person, and that it was not a permanent post, but rotated between different bishops even within their lifetimes, as the examples of Constantine and Senuthes discussed above also demonstrate.

What motivated the office's creation? In a context within which the parvenu bishops of the Severan episcopate confronted (more powerful) Chalcedonian rivals, and within which those bishops were staking a radical claim to represent the one true church, it must have been imperative that candidates for clerical office be vetted, and that moral and doctrinal discipline be maintained throughout the new church. In the archives of Pesynthius and Abraham, we perceive such concerns at the level of the individual see; but the institution of the vicarate extended them also to the regional level, creating a further level of oversight and of delegated power. In order to achieve this, the Severan patriarchs were forced to cede something of the absolutism which had accrued to Alexandrian patriarchs in the past; but the rotation of the vicarate between different sees was no doubt intended to prevent one bishop or see building a regional powerbase, and thus to maintain the traditional position of the patriarch. Thus - in the same manner that Peter and Damian were exploring the position of their new church vis-à-vis its equivalent in the Antiochene patriarchate - so too were the patriarchs innovating in the hierarchical organisation of the new episcopate.

\section{Conclusion}

During the long reign of Justinian, two Severan ascetics are said to have travelled to the court at Constantinople, and there to have confronted the Chalcedonian emperor over his persecution of the orthodox. The stories which purport to record these dramatic confrontations - these assertions of the ascetic prerogative of parrhēsia - belong however to two independent traditions: in Coptic, to the hagiographic corpus of

199 It is tempting to read a corruption of толотпрпти́s, but see the comments of W. E. Crum, Journal of Egyptian Archaeology 4, 1917, 209; also the commentary of D. N. Bell, Mena of Nikiou: The Life of Isaac of Alexandria \& the Martyrdom of Saint Macrobius, Kalamazoo, MI, 1988.

200 Mena of Nikiu, Life of the Patriarch Isaac ed. E. Porcher, Vie d'Isaac, patriarche d'Alexandrie de 686 à 689, écrite par Mena, évêque de Pchati, Patrologia Orientalis 11, 1915, 299-390, at 354. 
Abraham of Farshut, archimandrite of the Pachomian federation; ${ }^{201}$ and in Syriac, to the biography of the Mesopotamian stylite Z'ura within John of Ephesus's Lives of the Eastern Saints. ${ }^{202}$ We need not concern ourselves here with the truth of such narratives. ${ }^{203}$ For our purposes, we can instead underline the principles which each narrative expresses: both the significance of ascetics as the bearers of anti-Chalcedonian resistance; and the importance of imperial politics in shaping the self-perception of the emergent communities of anti-Chalcedonian Christians.

It is perhaps telling that in the Coptic tradition it is ascetics like Abraham - and his associates Apollo and Manasses ${ }^{204}$ - who are presented as the leaders of the resistance against Justinian's persecution, and not local bishops. Indeed, in an encomium on the aforementioned Apollo written between 536 and 822/3 and attributed to the otherwise unknown monk Stephen, later bishop of Herakleopolis Magna, the author informs us that after the patriarch Theodosius's exile and Justinian's persecution, churches were desolate and clerics few, and that most orthodox bishops had died. ${ }^{205}$ We might of course dismiss this as wilful hagiographic exaggeration. But we have seen that following Justinian's universal edict expelling anti-Chalcedonian bishops from their sees, Chalcedonian bishops had indeed been established along the length of the lower Nile, and that the Severan episcopate had gone into a converse, precipitous, decline, its members converted, displaced, or deceased. Although our evidence for the situation in the chora is exiguous, it is indeed probable that monasteries became - alongside a handful of scattered bishops, and the lowerorder clerics of Alexandria - the main proponents of Severanism, and that the hagiographic focus on monastic heroics was first generated in a genuine context of rapid episcopal retreat.

Recent research on the creation of the Severan-Jacobite church has also emphasised the importance of monasteries in maintaining the anti-Chalcedonian tradition in the face of persecution, and of the imperial policies of Justin I and of Justinian in precipitating the institutional and cultural formation of the new church. ${ }^{206}$ In the his-

201 See esp. Goehring, Politics, Monasticism, and Miracles (cf. n. 31); with id., "Chalcedonian Power Politics" (cf. n. 32).

202 John of Ephesus, Lives of the Eastern Saints (Brooks PO 1720 -24); with H. Leppin, "Power from Humility: Justinian and the Religious Authority of Monks," in A. Cain - N. Lenski (eds.), The Power of Religion in Late Antiquity, Farnham 2009, 155-64.

203 The ideological content of these stories is now examined alongside that concerning Sabas and Justinian (in Cyril of Scythopolis) in D. Neary, "The Image of Justinianic Orthopraxy in Eastern Monastic Literature,” Journal of Early Christian Studies (forthcoming).

204 See K. H. Kuhn, A Panegyric on Apollo Archimandrite of the Monastery of Isaac by Stephen Bishop of Heracleopolis Magna, CSCO 394-95, 2 vols, Louvain 1978. For the life of Manasses see A. Campagnano, Preliminary Editions of Coptic Codices, Rome 1985, with id., "Monaci egiziani fra V e VI secolo," Vetera Christianorum 15, 1978, 223-46, at 238-239 for a précis.

205 Stephen of Hnes, Encomium on Apollo 10 (cf. n. 204).

206 See esp. Menze, Making of the Syrian Orthodox (cf. n. 5); P. Wood, "We have no king but Christ”: Political Thought in Greater Syria on the Eve of the Arab Conquest, Oxford 2010. 
toriographical and hagiographic tradition of the Severan-Theodosian church, Justinian, in particular, also has a central place, in his role as persecutor of Theodosius and of Severan monastic communities. This imperial persecution is central to the later self-perception of the Severan church, since it delegitimises the Chalcedonian incumbents who replaced Theodosius from 536, and presents the patriarch's exile as the institutional bridge across the long decades in which no recognised Severan patriarch sat in Alexandria. But despite Justinian's prominence in later Severan narratives, his reign cannot be seen as the moment in which two churches here came into being; for his policies, and those of his successor Justin II (565-578), had in fact all but eliminated the Egyptian Severan episcopate, however much opposition to Chalcedon remained embedded within monasteries. The crucial reign, I have argued here, is instead that of Tiberius, whose de facto succession in late 574 encouraged the creation of a new Severan patriarch in Alexandria, and that patriarch's subsequent appointment of a host of new hierarchs. Where Justin II, upon his own succession, had earlier been able to suppress a similar initiative under the Gaianite Dorotheus, however, Tiberius proved unable or willing to prevent the process. The true bifurcation of the Egyptian church occurred, therefore, not with the exile of Theodosius in 536, but with the patriarchates of Peter IV (575-577) and of Damian (577-c.606).

In studies of Coptic literature the 'era of Damian' is often marked as a distinct stage, a period in which the bishops of the chora first started to produce original texts in Coptic, and to circulate them under their own names. ${ }^{207}$ But this remarkable production cannot and should not be separated from the processes of institutional formation which underpinned and informed it. Under Peter and Damian, nothing short of a new episcopate had been established throughout Egypt, on a scale which seems to have far outstripped the church of Jacob Baradeus. These bishops, several of whom were recruits from local monasteries, existed in direct competition with their Chalcedonian rivals, but their church was not a simple imitation of its Chalcedonian counterpart. On the international stage, where the precise inter-relation of the new Severan patriarchs was far from clear, Damian attempted to assert his dominance over the entire Severan commonwealth, and thus to carve out a radical new role as its ecumenical patriarch. But on the domestic stage too, in a context of the continued entrenchment of Chalcedonian bishops within cities, the new patriarchs also devolved some traditional Alexandrian powers to one or more regional vicars; while some of their bishops - like their equivalents in Mesopotamia and the Levant - placed their new residences in rural monasteries. Henceforth, therefore, there existed in Egypt two distinct episcopates, which in places occupied two distinct spaces. But it was the more recent - that of the bishops Pesynthius, Abraham, Constantine and their colleagues - which would prove the more successful and endur-

207 See above n. 8; with Booth, “A Circle of Egyptian Bishops” (cf. n. 7) for the contents, language, and significance of this literature. 
ing. The names of Peter and of Damian are not ones which loom large in our textbooks on the formation of eastern Christendom. But through their actions in forming a new patriarchate, and in creating a new episcopate, the future of the faith within the Near East had been set along a different path, a path which far departed from the late antique ideal of a single, universal church. 
